\title{
21. NEOGENE TUFFS, ASHES, AND VOLCANIC BRECCIAS FROM OFFSHORE CALIFORNIA AND BAJA CALIFORNIA, DEEP SEA DRILLING PROJECT LEG 63: SEDIMENTATION AND DIAGENESIS ${ }^{1}$
}

\author{
V. I. Grechin ${ }^{2}$, A. R. Niem³ , R. O. Mahood ${ }^{3}$, V. A. Alexandrova 2 , and B. A. Sakharov ${ }^{2}$
}

\section{INTRODUCTION}

Tuffaceous sediments and rocks form a small part of the total stratigraphic section cored at seven Leg 63 sites off the coasts of southern California and Baja California (Fig. 1). Tuffs and ashes occur as thin interbeds intercalated with middle Miocene to Quaternary strata of various lithologies (Figs. 2A and B). At Sites 467, 468 , and 469 , however, tuffs and associated volcanic breccias comprise a significant part of the middle and middle upper Miocene stratigraphic interval (Fig. 2). This chapter discusses the mineralogy, geochemistry, alteration, and sedimentology (depositional processes and settings) of the pyroclastics and associated volcanic breccias. We do not include an interpretation of provenances of the volcanic sandstone, breccia, and tuff at Sites 467,468 , and 469 , which is discussed by Vedder and others in this volume.

Little is known about the depositional processes, lateral and vertical variation, and alteration of marine volcanogenic sediments. Several recent studies suggest that submarine pyroclastics and volcaniclastics can originate from (1) submarine ignimbrites or ash flows; (2) pyroclastic flows or lahars; or (3) turbidity currents, grain flows, ash falls into water, and by other current reworking processes (Lajoie, 1979; Tasse et al., 1978; Niem, 1977; Yamada, 1973; Bond, 1973; Fernandez, 1969; Mutti, 1965; Fiske and Matsuda, 1964). Criteria to distinguish the origins of these deposits are not always unique, however, and may overlap, leading to possible misinterpretation.

The composition, texture, and lithologic character of these sequences can also provide important clues to the tectonic setting and nature of the volcanic activity within or adjacent to the marine basin of deposition. For example, middle Miocene andesitic, dacitic, and minor basaltic volcanic activity has been well recognized in the Channel Islands of the California Continental Borderland (Fisher and Charlton, 1976; Howell and McLean, 1976). Widespread evidence of Miocene calcalkaline volcanism in Leg 63 cores, however, so close to the inferred Farallon-North American trench at the base of the continental slope conflicts with previous plate tectonic interpretation of the area (see Vedder and others, this volume).

\footnotetext{
1 Initial Reports of the Deep Sea Drilling Project, Volume 63.

2 Geological Institute, U.S.S.R. Academy of Sciences, Moscow, U.S.S.R

${ }_{3}$ Department of Geology, Oregon State University, Corvallis, Oregon.
}

Furthermore, there has been controversy over the relative importance of burial depth (pressure), temperature, age, and composition as factors in the processes of diagenesis and alteration of subaqueous pyroclastics. Because the volcanogenic strata encountered in the Leg 63 holes range from middle Miocene to Quaternary and vary in composition, we hoped that insights into the relationships of depth of burial (pressure), temperature, age, and composition, and timing of diagenetic alteration could be gained.

\section{TERMINOLOGY}

In general, the nomenclature and classification of pyroclastic deposit\$ and fragments in this report conform with the terminology recommended by the International Union of Geological Sciences (IUGS) Subcommission on the Systematics of Igneous Rocks (Schmid, 1981). Because the terminology in current geologic literature for some pyroclastics may differ somewhat from that used in this report, some terms require definition or further explanation.

Volcanogenic-a general term applied to clastic sediments consisting of volcanic material.

Pyroclastic-applied to fragmental products of explosive volcanism.

Epiclastic-applied to products of terrigenous erosion and weathering of volcanic rocks.

Volcaniclastic-refers to all fragmental volcanic rocks that result from any mechanism of fragmentation.

Scoriaceous tuffs-rocks composed mostly of vesicular glass of basaltic or less commonly of andesitic composition. These are products of explosive volcanism, probably subaqueous or subaerial phreatic eruptions, rather than granulation or quenching of lava that flows into or is erupted under water, which typically forms hyaloclastites.

Vitric tuff-a pyroclastic deposit dominantly composed of glass shards and volcanic dust.

Ash (tuff if lithified)-pyroclastic fragments $<2 \mathrm{~mm}$ in diameter (coarse ash is $1 / 16-2 \mathrm{~mm}$, fine ash $<1 / 16$ $\mathrm{mm}$ ).

Lapilli-pyroclastic fragments $2 \mathrm{~mm}$ to $64 \mathrm{~mm}$ in diameter.

Pumice-frothy, light-colored, long-tube vesicular glass fragments, generally dacitic to rhyolitic composition.

Scoria-dark-colored, vesicular glass fragments containing spherical vesicles, commonly basaltic or more rarely andesitic in composition. 


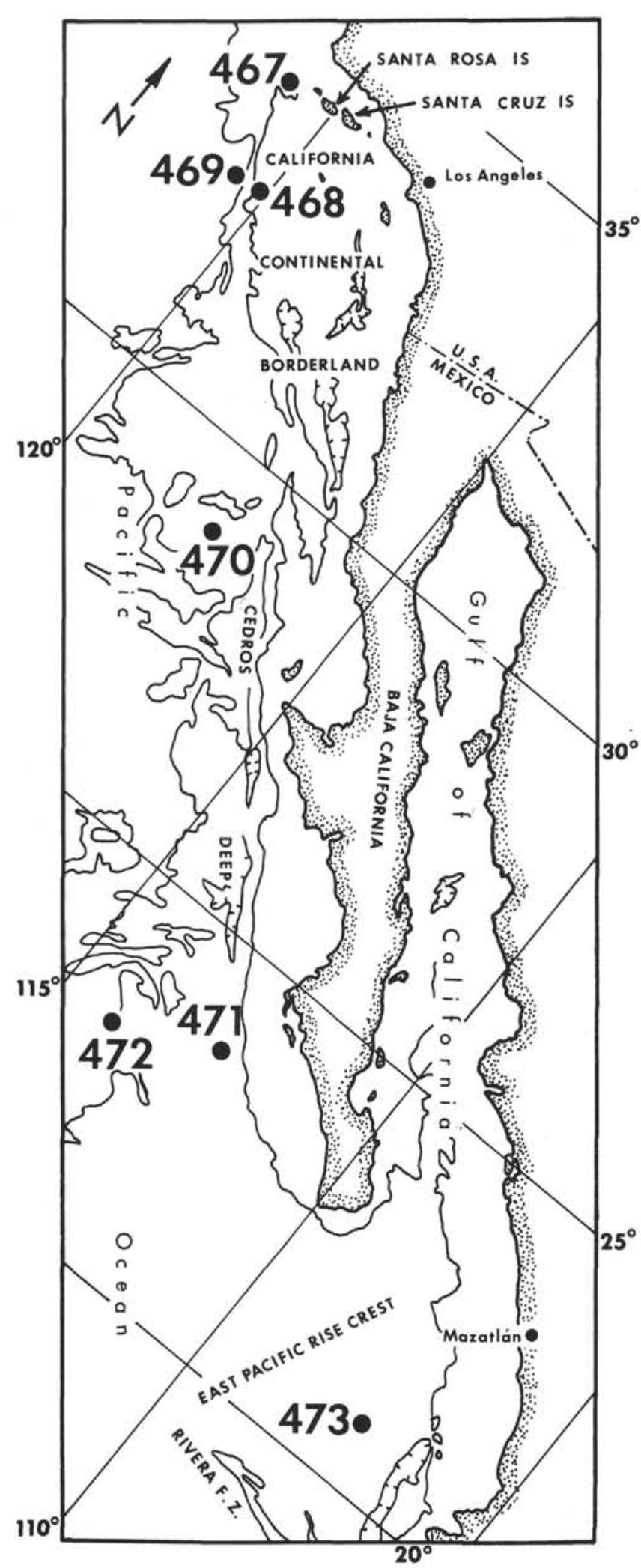

Figure 1. Location map of Leg 63 sites.

\section{Methods}

Methods utilized in analysis of the volcaniclastic strata include X-ray diffraction of clays and zeolites, petrographic study, scanning electron microscopy, wet chemical techniques, heavy mineral separa- tion, refractive index determination of glass shards, and study of sedimentary structures in the cores.

Clay minerals from the $<1-\mu \mathrm{m}$ fraction were studied by X-ray methods. Diffractograms were obtained by means of a DRON-1 diffractometer (U.S.S.R.), using Ni-filtered $\mathrm{CuK}_{\alpha}$ radiation at $34 \mathrm{kv}$ and $20 \mathrm{~mA}$ scanned at $2^{\circ} 2 \theta$ per minute. Four diffractograms were obtained for each oriented sample: (1) air-dried, (2) saturated with glycerine, (3) heated at $550^{\circ} \mathrm{C}$, and (4) heated partly at $400^{\circ} \mathrm{C}$ and $300^{\circ} \mathrm{C}$. In addition, random powder mounts were scanned slowly between 59.0 and $62.5^{\circ} 2 \theta$ to study the (060) reflections. A total of 18 samples from Sites $467,468,469,471$, and 473 were analyzed by these $\mathrm{X}$-ray techniques. Some samples were studied by means of oblique texture electron diffraction.

Grain size fractions $(0.01-0.05 \mathrm{~mm}, 0.05-0.1 \mathrm{~mm}$, and $0.1-0.25$ $\mathrm{mm}$ ) of 11 samples were separated by sieving for study of zeolites and $\mathrm{K}$-feldspar. K-feldspar was then segregated from zeolites by settling through different heavy liquid mixtures of bromoform and dimethylformamide. Specific gravity of the liquid mixtures ranged from 2.1 to $2.7 \mathrm{~g} / \mathrm{cm}^{3}$ in increments of $0.05 \mathrm{~g} / \mathrm{cm}^{3}$. Specimens of each density fraction were then mounted on glass slides by drying of a water suspension. Diffractograms were run using $\mathrm{CuK}_{\alpha}$ radiation at $34 \mathrm{kv}$ and $20 \mathrm{~mA}$ and a scanning rate of $2^{\circ} 2 \theta$ per minute. Hand-picked fractions of zeolites and feldspar were photographed with a Debye-Scherrer powder camera, utilizing a Phillips X-ray generator with nickel-filtered $\mathrm{CuK}_{\alpha}$ radiation to further aid in identification of the alteration minerals.

Chemical analyses were performed by wet chemistry techniques at the chemical analytical laboratory of the Geological Institute of the U.S.S.R. Academy of Sciences. International standards of basalt BR and diorite DR-N were used to establish the accuracy of analyses from this laboratory (Zolotarev and others, 1979).

Sedimentological aspects of this chapter are based on observations made on board and during a postcruise visit to the Scripps core repository. Surface microtextures of hand-picked pyroclasts from several samples were observed and photographed using an International Scientific Instrument mini-SEM (scanning electron microscope) after coating with gold.

\section{GEOLOGIC SETTING AND STRATIGRAPHY}

Sites 467 and 468 are located on the southern California Continental Borderland in the vicinity of the northern Channel Islands (Fig. 1). The outer borderland contains a Miocene and younger sequence that overlies a probable Franciscan-like basement (Vedder et al., this volume). The borderland constitutes a broad transition zone between continental rocks of California and oceanic crust at the foot of the Patton Escarpment where Hole 469 was drilled. Holes 470,470 A, 471, and 472 were drilled on the abyssal seafloor west of the continental slope off Baja California. Hole 473 was cored on oceanic crust near Tres Marias Islands south of the mouth of the Gulf of California and the East Pacific Rise crest (Fig. 1).

At Site 467 a volcanogenic unit was penetrated at a sub-bottom depth of 699.5 to 832.5 meters. This unit was deposited in the middle to late Miocene. It consists of altered scoriaceous vitric tuff and thicker scoriaceous lapilli tuff ( $2 \mathrm{~mm}$ to $2 \mathrm{~m}$ thick) interbedded with subordinate bioturbated clayey nannofossil chalk and calcareous claystone. Chert breccia, calcite-filled fractures, and thin fine-grained, carbonate-cemented epiclastic sandstone beds occur in the lower part of the unit.

At other southern California borderland sites (468 and 469), the middle Miocene volcanogenic-rich section contains medium to thick beds $(0.3 \mathrm{~m}$ to $1.2 \mathrm{~m})$ of volcanic breccia, epiclastic pumiceous lapilli tuff, altered vitric tuff, and associated volcaniclastic sandstone in a sedimentary sequence that is predominantly silty clay- 
stone. Beds of porcellanite, nannofossil claystone, and dolomitic claystone also occur.

All the Miocene volcanogenic-rich strata encountered in the three sites in the borderland are overlain by a thick sequence of middle Miocene to Quaternary clay, silty clay, nannofossil and diatom oozes, and their lithified equivalents. A few scattered thin $(2-\mathrm{mm}$ to $23-\mathrm{cm}$ thick) beds and drilling-produced mottles of unaltered Pliocene and Quaternary vitric and pumiceous ashes are present.

Oceanic basaltic crust is overlain by middle Miocene to Quaternary sediments in Holes 470, 470A, 471, and 472 and by upper Miocene to Quaternary strata at Hole 473. The stratigraphic sequence at these Baja California sites consists of thick clay and nannofossil and diatom oozes with a few very thin beds and mottles of unaltered fine to coarse vitric ash (Fig. 2B). The ashes are white and gray and are not more than a few centimeters thick. The lower part of the section at Sites 471 and 473 (161$741 \mathrm{~m}$ and $143-248 \mathrm{~m}$, respectively) is composed of feldspathic sandstone turbidites, porcellanite, and some thin ( $<3$-cm-thick) beds of altered greenish gray vitric tuff.

\section{TEXTURES, BEDDING STYLES, AND SEDIMENTARY STRUCTURES}

Grain sizes of the Miocene tuffs at Sites 467,468 , and 469 vary from fine ash to lapilli. Lapilli tuffs are poorly sorted, whereas fine and coarse ash vitric tuffs are more commonly moderately sorted. Colors of the tuffs range from bluish gray to greenish gray. The lapilli consist of angular to subangular light and dark gray pieces of altered highly vesicular scoria at Site 467 . In contrast, epiclastic lapilli tuff and volcanic breccia at Sites 468 and 469 commonly contain well-rounded to subangular fragments of pumice, perlitic glass, lavas, and shells, indicating a prior history of abrasion in a shallow-marine environment (Figs. 3 and 4). Coarse to fine ash vitric tuff is composed of sickle-shaped and bubble-wall shards to irregular shaped shards and pumice shards (shard terminology after Pirsson, 1915). Primary shard shapes and the textures of many altered vitric tuffs have been largely obscured by alteration of the glass to smectite and formation of an extensive diagenetic clay matrix. Some volcanic breccias (e.g., Section 469-33-1) contain a detrital matrix of diatomaceous silty clay.

Tuff beds range from $<2-\mathrm{mm}$ thick (laminae) to $122-\mathrm{cm}$ thick (very thick-bedded). The lower contact of each bed is sharp (Fig. 5A). The upper contact of the thicker beds $(>30 \mathrm{~cm})$ is commonly gradational and/or bioturbated with the overlying claystone and/or chalk. Reworked fine ash infills tiny burrows at the upper contacts of Hole 467 tuffs (Fig. 5B). Both the top and bottom contacts are sharp in thin tuff beds. In Hole 467, the number of tuff beds, their thickness, and grain size are greatest in the middle part of the Miocene volcanogenic unit (Fig. 2A; Cores 79-82; 737.5 m-777.5 m). Also in this part of the section, many thicker lapilli tuff beds are amalgamated; i.e., composites of two or more graded or structureless pyroclastic units. These bedding styles reflect a general coarsening and thickening up- ward trend followed by a fining and thinning upward pyroclastic sequence. Bedding styles in Hole 469 include thin sequences of interlaminated vitric tuff and claystone (Core 37, Sections 1 and 2), thick amalgamated vitric tuff composed of two moderately sorted pumiceous graded units (Section 469-37-1), structureless to thoroughly bioturbated fine ash tuff (Section 469-37-1), and an overlying coarse volcanic breccia-pumice lapilli tuff (Section 469-33-1).

Sedimentary structures in the Miocene tuffs of Holes 467, 468, and 469 include Bouma sequences $\mathrm{T}_{\text {abe }}$ (Fig. 5B) and $T_{c d}$ with rarer $T_{\text {cde }}$ (Figs. 5A and 5C). These sequences consist of normal and minor reversed graded bedding (e.g., 467-85-4; 467-79-2), parallel laminations (469-37, CC; 469-37-1), and microcross-laminations (46779-2). Load casts, lapilli penetrations of bedding, and scour features occur at the base of some tuff beds (Section 467-85-4; Sample 467-86-1, 0-16 cm; Fig. 5A). Mudstone rip-ups (467-85-4) and some penecontemporaneous slump folding or prolapsed bedding are present in thinly laminated vitric tuffs (467-86-3; 469-36-2). Contorted bedding occurs in some tuffaceous sandstone beds (Fig. 6A). Interbedded light and dark gray nannofossil chalk (Site 467) and/or olive gray dolomitic silty claystone (Sites 468 and 469 ) between tuff beds display lenticular bedding, slump structures, laminations, small white sponges, and extensive bioturbation. Common trace fossil forms in Hole 467 include Zoophycos (467$85-2$ ), composite (467-79-4) and rind burrows, Teichichnus (467-83-2), and Chondrites (Fig. 6B).

Middle Miocene epiclastic breccia and tuff at Sites 468 and 469 display size and density grading and/or segregation of pyroclastics from rock and mineral fragments. Four types of graded or lithologic sequences occur: (1) One type is very poorly sorted volcanic breccia composed of framework-supported fragments of andesitic and basaltic lavas (Fig. 3), overlain by moderately well-sorted medium-grained volcanic sandstone (468B34-1). (2) Some volcanic breccia units (Fig. 6C) grade upward into pumiceous lapilli tuff, which is composed of thin pumice-rich layers and finer-grained volcanicrich layers with abundant shell, crinoid, and bryozoan fragments (469-33-1; Fig. 6D). The long axes of the pumice and shell fragments are aligned parallel to bedding. (3) In some cores, thick structureless well-sorted, medium-grained, volcanic sandstone is overlain by an associated layer of pumice lapilli (e.g., 468B-26-1). (4) Or a sequence may consist of a thick amalgamated bed composed of interstratified thin to laminated epiclastic tuffaceous sandstones and thin-bedded, pumice-rich layers (468B-37, Sections 1 and 2). In one core (468B$17-4$ ), isolated pumice lapilli (up to $3 \mathrm{~cm}$ long) occur in a thick, silty, claystone sequence (Fig. 7).

Unaltered vitric ashes and altered tuffs in Holes 470, $470 \mathrm{~A}, 471,472$, and 473 are composed of fine to coarse ash-sized glass shards and some crystals, are moderately well-sorted, and have sharp contacts with adjacent lithologies. The ashes and tuffs generally appear as structureless mottles and distorted beds in the cores mainly because of drilling disturbance, although a few thin 


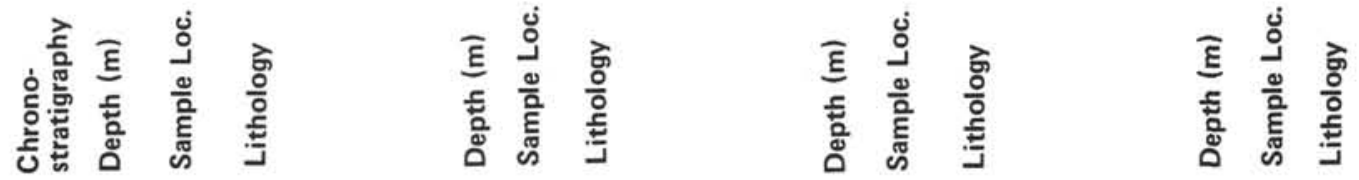

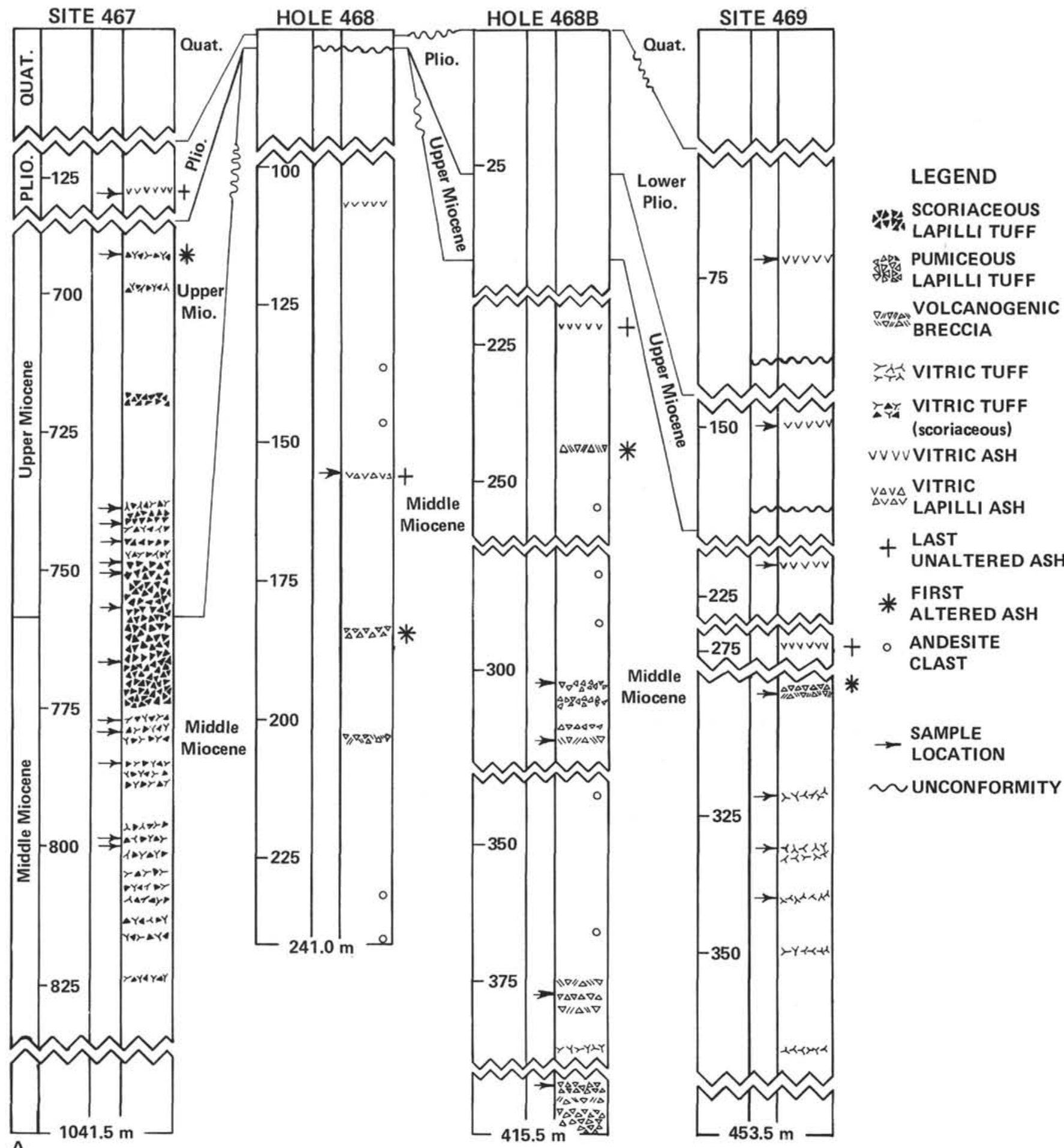

A.

Figure 2. A. Tuffs, ashes, and volcanic breccias from southern California Holes 467, 468, 468B, and 469. (Chronostratigraphic assignments follow the usage of Bukry [this volume].) B. Tuffs and ashes from Baja California Holes 470, 470A, 471, 472, and 473. (Chronostratigraphic assignments follow usage of Bukry [this volume].) 

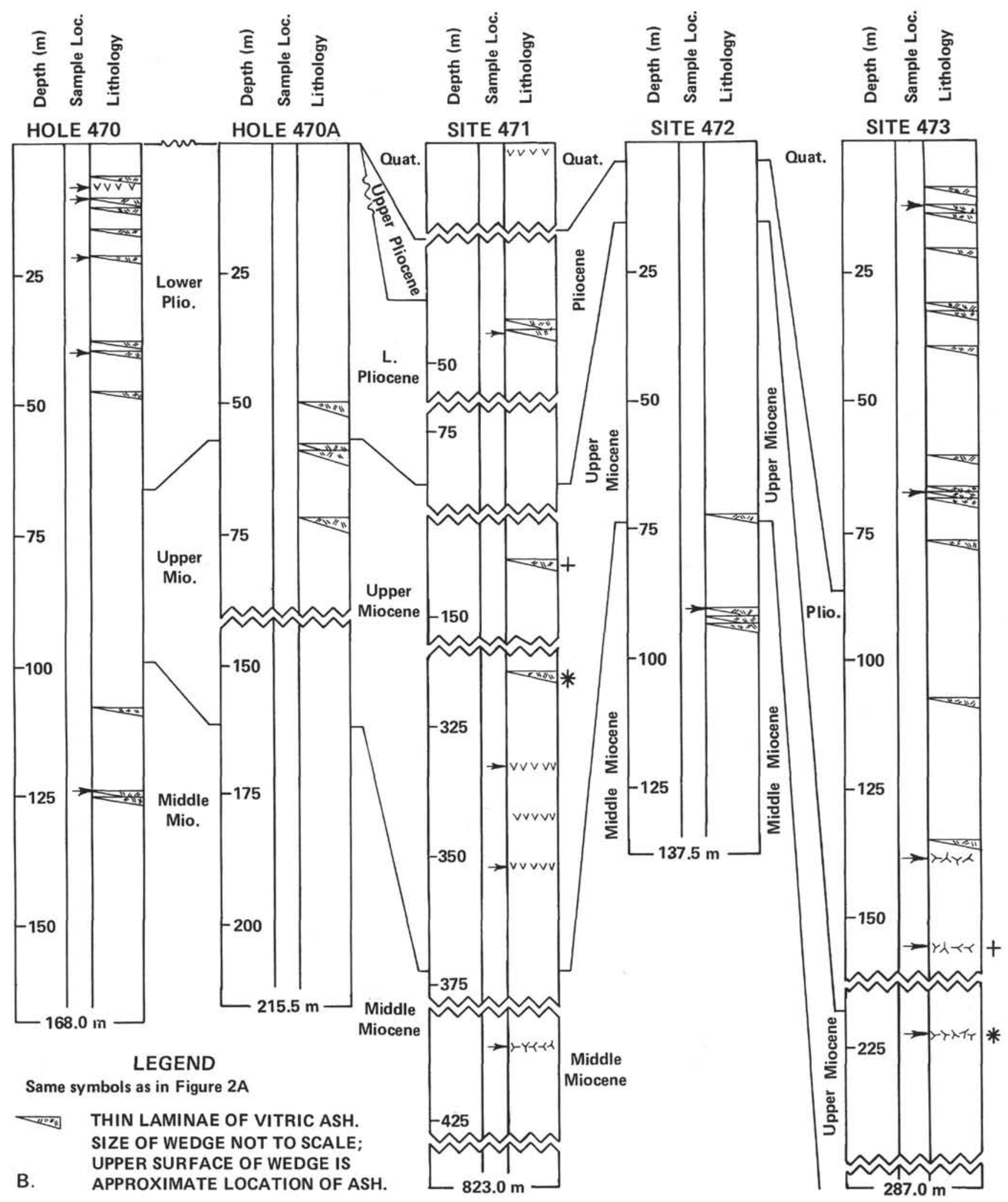

Figure 2. (Continued). 


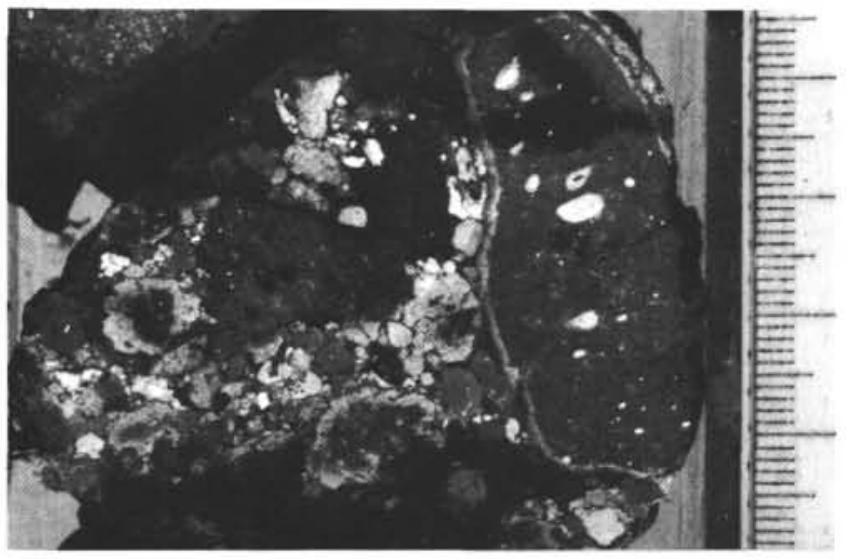

Figure 3. Poorly sorted middle Miocene volcanic breccia with subangular to subrounded amygdaloidal andesite and basalt clasts, Sample 468B-34-1, 88-107 cm. (Metric scale is in millimeters.)

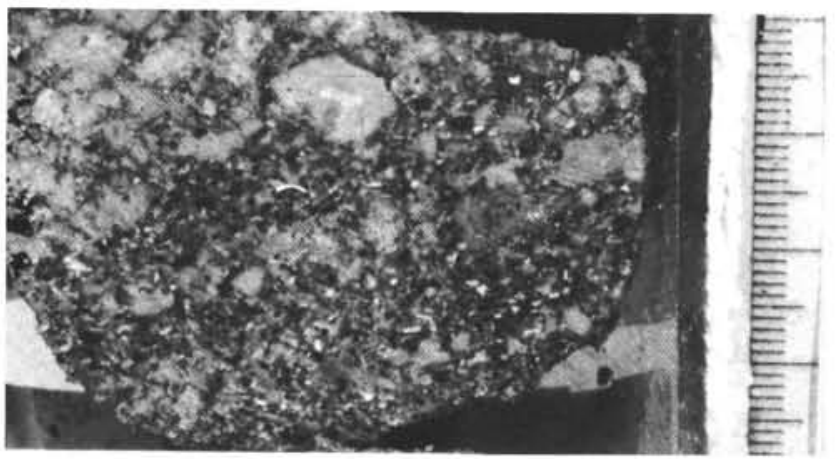

Figure 4. Miocene pumice lapilli tuff with pelecypod shells and other biotics scattered throughout. (Small dark clasts are nonvesicular lava fragments and perlitic glass. Sample 469-33-1, 5-10 cm. Metric scale is in millimeters.)

( $<6$-cm-thick) undisturbed tuff beds occur (e.g., Section 471-44-3). The base of some beds is slightly crystalenriched.

\section{DISCUSSION}

The sedimentary structures, textures, and bedding styles of the Miocene tuffs and volcanic breccias indicate that most of these beds were deposited by turbidity currents. Scour features, mudstone rip-ups, Bouma sequences $T_{\text {abe }}, T_{\text {cde }}$, and $T_{\text {de }}$, and organized volcanic breccia-pumice lapilli tuff units suggest that these are deposits from both high- and low-density turbidity currents (Middleton and Hampton, 1973; Walker and Mutti, 1973). The thicker, coarse-grained, nearly structureless, and poorly sorted amalgamated breccias and lapilli tuffs at Sites 467 and 468 are composed of angular clasts of andesite, basalt, or pumice lapilli and may be debris flow deposits (Middleton and Hampton, 1973; Walker, 1975). Some thin cross-laminated tuffs may have been deposited by bottom currents.

The size and density grading or segregation of pumice lapilli from sand-sized crystals and lava fragments in the Miocene strata of Holes 468 and 469 is a common feature in subaqueous pyroclastic turbidite sequences (La- joie, 1979). Density grading reflects hydrodynamic separation of the larger but less dense pumice lapilli from the smaller but more dense crystals and/or larger more dense volcanic rock fragments during turbulent flow (Fiske and Matsuda, 1964; Niem, 1977). Load structures, slump folds, and distortion of primary parallel laminations (convolute bedding) in the Miocene tuffs and in the underlying claystone and chalk are evidence of rapid loading during deposition.

The general upward coarsening, thickening, and amalgamation in the Miocene scoriaceous tuffs in Hole 467 , which is followed by an overall fining and thinning upward trend of this pyroclastic sequence, may be interpreted as a small submarine channel-fill or a prograding depositional lobe that was subsequently abandoned. Alternatively, these vertical changes of bedding style and grain size may reflect increasing intensity and size of eruptions followed by waning of the basaltic volcanism that produced the scoriaceous tuffs in Hole 467. The geometry of the deposits would have to be known in order to decide which of the above hypotheses is more likely.

The trace fossils, Zoophycos, composite and rind burrows, Teichichnus, and Chondrites, in the hemipelagic claystone and pelagic chalk that are interbedded with the Miocene tuff and volcanic breccia at the California borderland sites belong to the Zoophycos trace fossil assemblage. Chamberlain (1978) reported many of these forms in cores from other DSDP legs; he interprets these to indicate deposition at bathyal to abyssal depths (e.g., on the continental slope or in a slope basin).

Displaced shallow-water fauna, including barnacles (see Vedder and others, this volume), echinoid plates, bryozoa, and broken pelecypod shells in the Miocene lapilli tuff and volcanic breccia at Sites 468 and 469 indicate that the epiclastic volcanogenic detritus was initially deposited in a shallow agitated shelf or surf environment. This volcaniclastic debris was subsequently redistributed downslope by turbidity currents and debris flows.

The degree of reworking (rounding) and admixture of other volcaniclastic (e.g., lava fragments) and terrigenous detritus varies from site to site. There is little rounding of the scoria and almost no admixture of terrigenous (i.e., nonpyroclastic) debris in the middle to upper Miocene tuff in Hole 467. This suggests that the pyroclastic material was freshly erupted and initially deposited at a nearby location that was relatively isolated from sources other than the basaltic or possibly andesitic volcanism. Vedder and others (this volume) also suggest, from a provenance study of these volcaniclastics and the surrounding seafloor and island outcrops, that Site 467 was relatively isolated (perhaps by a strike-slip fault) from potential nearby Channel Island sediment sources during the middle to late Miocene (such as the Blanca Formation on Santa Rosa and Santa Cruz islands).

The morphology of altered vesicular shards and scoria fragments observed under SEM and thin sections at Site 467 is similar in shape and outline to the frag- 

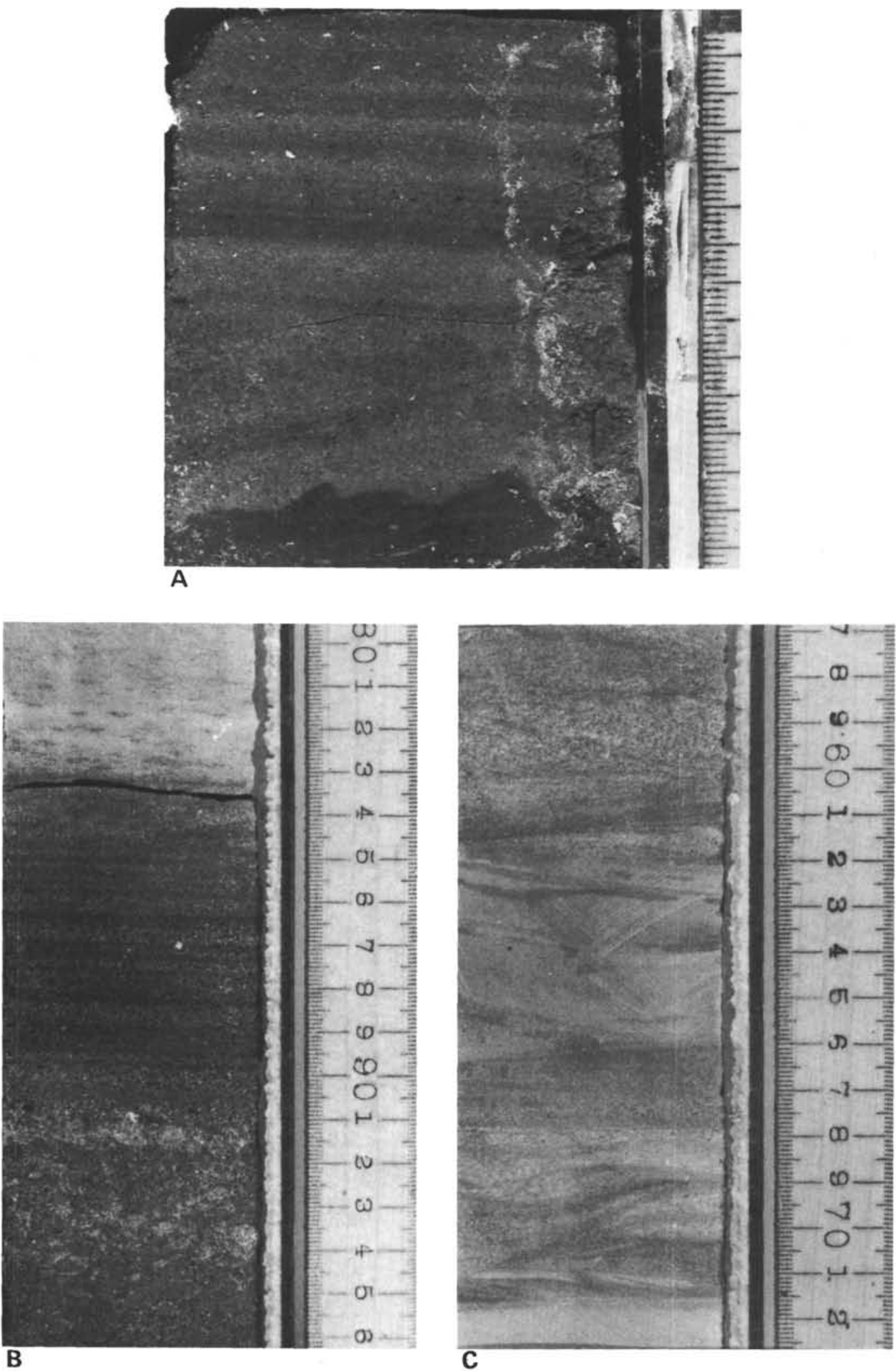

B

\section{C}

Figure 5. A. Altered Miocene vitric tuff with sharp irregular scoured base on darker silty claystone. (Tuff grades upward from faint cross-laminations to a parallel laminated interval, Bouma sequence $T_{\text {cd }}$. Sample 469-37, CC (0-7 $\mathrm{cm}$ ). Metric scale is in millimeters.) B. Massive Miocene altered scoriaceous vitric tuff (Bouma A division) grades upward to parallel laminated (Bouma B division) tuff and overlying light-colored burrowed nannofossil chalk. (Sample 467-79-2, 80-95 cm. Metric scale is in millimeters.) C. Two layers of microcross-laminated altered scoriaceous vitric tuff (Miocene). (Sample 467-79-2, 55-73 cm. Metric scale is in millimeters.) 

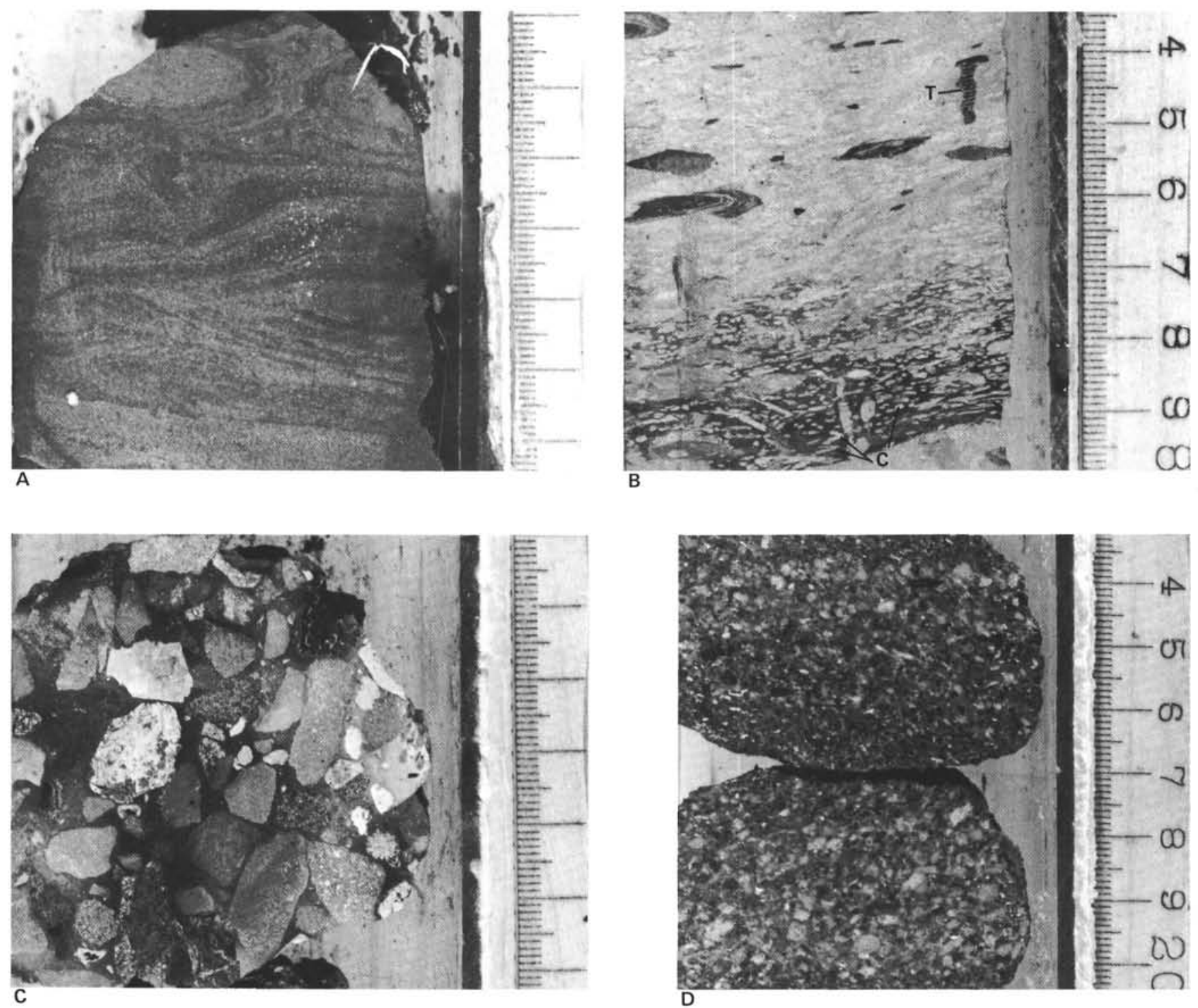

Figure 6. A. Cross-bedding and contorted bedding in a fine-grained altered tuffaceous sandstone (Sample 469-38-2, 48-58 cm; metric scale is in millimeters.) B. Trace fossils in nannofossil chalk between scoriaceous tuff beds. (Fossil forms include vertical, back-filled Teichichnus burrow [T], small light-colored Chondrites tubes [C], and large dark halo and Zoophycos[?] burrows. Sample 467-83-2, 74-81 cm. Metric scale is in millimeters.) C. Volcanic breccia composed of angular fragments of andesite, basalt, and basaltic glass (tachylyte) in a diatomaceous silty claystone matrix. (Sample 469-33-1, 100-105 cm. Metric scale is in millimeters.) D. Lapilli tuff that gradationally overlies volcanic breccia in Figure 6C. (Note coarse-grained pumice lapilli-rich layers interbedded with fine-grained volcanic-rich layer. Shell and other biotic fragments are scattered throughout. Sample $469-33-1,15-20 \mathrm{~cm}$. Metric scale is in millimeters.)

mental products pictured by Heiken (1972) from recent magmatic and phreatomagmatic basaltic volcanism in Hawaii, Guatemala, and on the island of Surtsey, Iceland.

The highly vesicular nature of the scoria also suggests that the eruptive source was in relatively shallow water. According to McBirney (1963) and Bonatti (1970), explosive formation of ash from basaltic magma is unlikely in water deeper than 500 meters, because the high pressure of seawater would prevent vesiculation of the magma and escape of the gas. Repeated phreatomagmatic eruptions of large volumes of vesiculating magma from a partially submerged vent could produce base surges (Fisher and Waters, 1970) or steam-inflated slurries (Fiske and Matsuda, 1964; Niem, 1977; Yamada,
1973). These flows, when mixed with seawater, could have formed turbidity or pyroclastic flows of partly cooled or quenched scoriaceous debris that flowed downslope to Site 467 . Alternatively, the cooled basaltic scoria may have settled rapidly from a shallow submarine or subaerial eruptive column on unstable submarine slopes around the vent, then at a later time slumped down the volcanic flanks to Site 467 . Such an eruption mechanism was proposed by Fiske (1963) for pumiceous pyroclastic flow deposits in the Eocene Ohanapecosh Formation in the state of Washington.

Middle Miocene tuff from Holes 468, 468B, and 469 contains both unrounded and rounded volcanogenic debris. The well-rounded and sorted detritus in some beds of volcanic breccia and tuffaceous sandstone indi- 


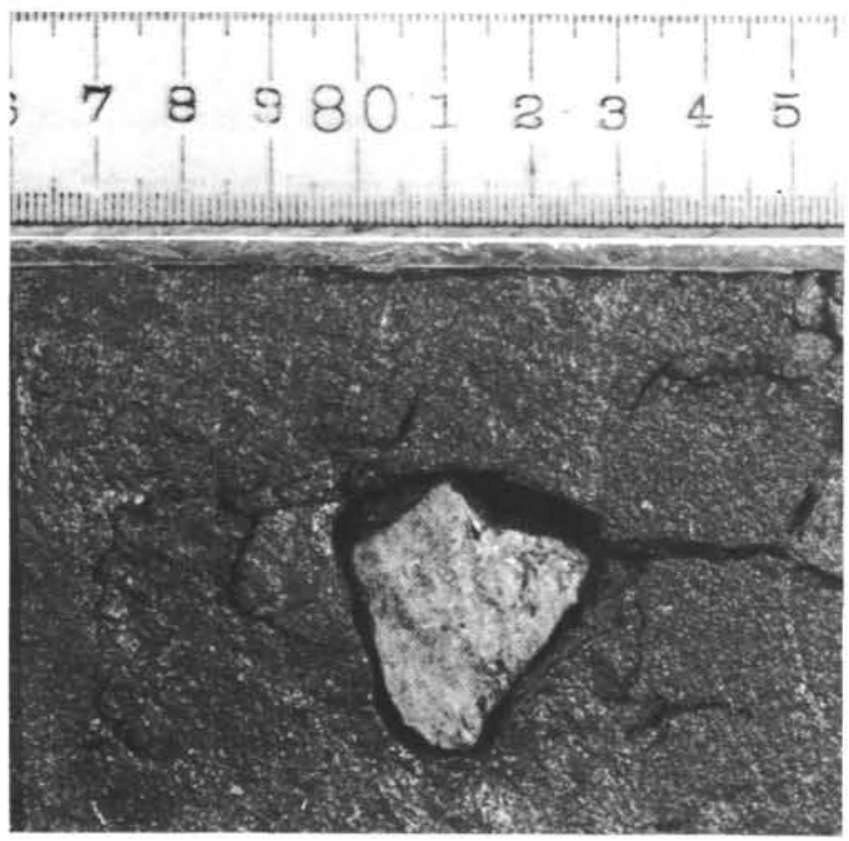

Figure 7. Pumice lapilli in a diatomaceous silty claystone (Sample 468B-17-3, 76-85 cm. Metric scale is in millimeters.)

cates a high degree of reworking of the pyroclastic and volcanic debris, possibly in the wave zone around a small oceanic island(s) prior to slumping and formation of turbidity currents that carried this debris to Sites 468 and 469 . The coarseness and angularity of some pyroclastic and volcanic material in the breccia also testify to the proximity of the vents from which they originated. Some turbidity current-formed sedimentary structures and epiclastic rounded pyroxene andesite-basaltic pebbles and dacitic pumice debris in the middle unit of the middle Miocene Blanca Formation (Howell and McLean, 1976; McLean and others, 1976) exposed on Santa Rosa and Santa Cruz islands (Fig. 1) are similar to the features in the tuff and volcanic breccia in Holes 468, 468B, and 469. Howell and McLean (1976) pictured a depositional model for the Blanca Formation forming from a continuum of pyroclastic or debris flows into water and pyroclastic turbidity flows down a submarine fan or channel system. Miocene pumiceous lapilli tuff and volcanic breccia in Holes 468 and 468B were probably developed in a similar but separate and more distal, deeper water setting, because they contain thick interbeds of hemipelagic silty claystone.

The dacitic-rhyolitic pumice and shards in the tuffs and ashes of Holes 468, 468B, 469, 470, 471, and 472 are typically formed from highly explosive eruptions of vesiculating acidic magma. Many thin interbeds of unaltered vitric ashes and altered vitric shard-rich tuffs at Sites 470, 471, 472, and 473 and the upper parts of the section at Sites 467 through 469 lack evidence of any reworking by currents. That is, there are no Bouma sequences, no shallow-water fauna or well-rounded. volcaniclastic material, and little or no nonvolcanic terrigenous debris. These thin beds probably are ash fall deposits formed from settling of ash through a deep water column from wind-borne ash clouds or currentwafted submarine eruptive clouds. Pelagic fauna (e.g., diatoms, coccoliths, foraminifers) are commonly intermixed with these well-sorted, fine-grained ashes. A high degree of sorting, fine ash grain size, and thin-bedded or laminated structure are characteristic of many modern and ancient subaerial and subaqueous ash fall deposits (Lajoie, 1979; Niem, 1977; Sheridan, 1971; Fiske, 1963; Murai, 1961).

The few isolated lumps of pumice in the thick, structureless Miocene silty claystone sequence in Hole 468B (Core 17) may be pieces of pumice that floated over the area, became water-logged, and sank.

The relatively isolated oceanic setting of these thin dacitic to rhyolitic fine ashes in pelagic and hemipelagic sediments overlying basaltic crust far from silicic eruptive sources at the Baja sites also supports an origin by ash fall into water for most of these thin vitric ashes and altered tuffs.

Presently, these Baja sites are in the northeast tradewind belt. The nearest intermediate to silicic volcanic eruptive sources would be in Baja California and the Mexican mainland. Gastil and others (1979) report widespread calc-alkaline volcanism (ranging in composition from basalt to rhyolites) from the middle Miocene to the Holocene around the Gulf of California on Baja and the mainland of Mexico. No attempt has been made here, however, to reconstruct the positions of these sites relative to the mainland and Baja with plate movements (see Yeats and Haq, this volume).

\section{PETROGRAPHY}

Data plots derived from point counts of 22 thin-sectioned samples from Holes 467, 468, 468B, and 469 show that all Miocene pyroclastic rocks classify as vitric tuff on the IUGS ternary classification diagram (Schmid, 1981; Fig. 8). Volcanic breccias from Site 469 and Hole 468B are lithic tuff (Fig. 8), although the low percentage of pyroclastics in these breccias limits the usefulness of this diagram to classify these deposits. Four major varieties of volcanogenic rocks in Leg 63 drill holes are defined on the basis of mineralogical composition as well as by textures and sedimentary structures. These varieties are: scoriaceous lapilli tuff and vitric tuff; pumiceous lapilli tuff; volcanic breccia; and vitric ash-tuff.

\section{Scoriaceous Tuff}

Altered scoriaceous tuff occurs only in the middle to upper Miocene volcanogenic unit in Hole 467. These pyroclastics predominantly consist of extensively altered, vesicular, lapilli-sized, glassy fragments of scoria and coarse, ash-sized, scoriaceous glass shards (Fig. 9A). Only a few unaltered brownish glass shards (tachylyte) with palagonitized clay-altered rims and nonvesicular basalt lava fragments with an intersertal texture are present. Other minor components are: fragments of altered long-tube pumice, albite-twinned plagioclase, monocrystalline quartz, glauconitic pellets, and collophane-coated grains. Heavy minerals include authigenic 


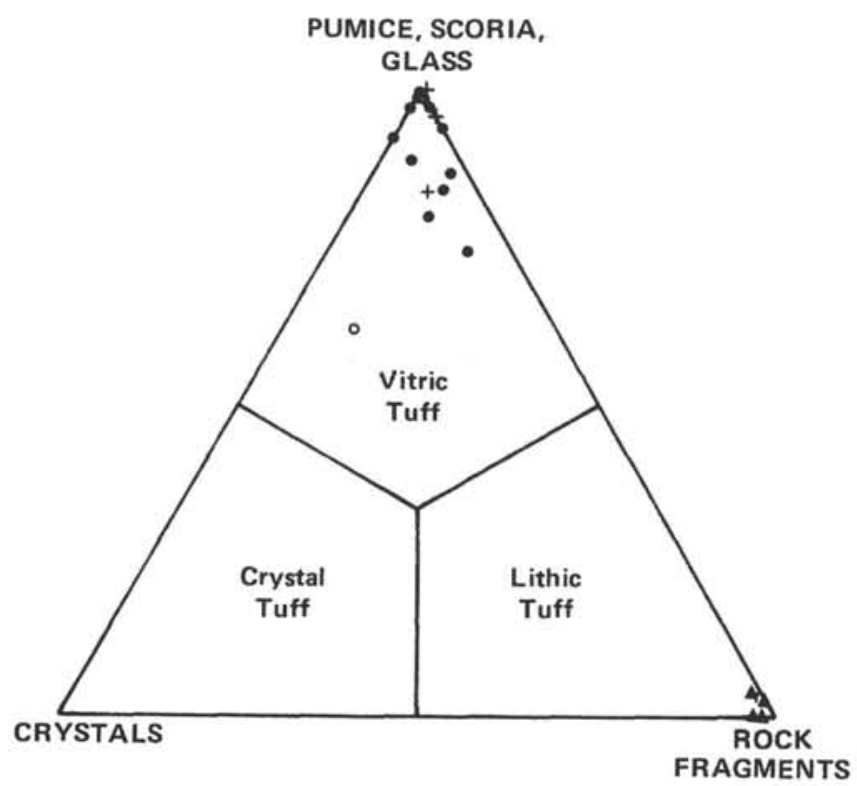

- SITE 467 tuff

- HOLE 468B tuff

+ SITE 469 tuff

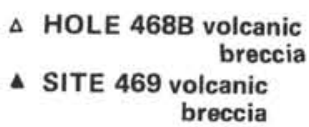

Figure 8. Classification diagram (after International Union of Geological Sciences, IUGS; Schmid, 1981) for pyroclastics and volcanic breccia from Sites 467 through 469 . (For each sample 500 points were counted.)

pyrite and scarce barite. Some tuff beds contain scattered foraminifers, diatoms, and radiolarian fragments.

Lapilli-sized scoria fragments are generally angular, elongate to irregular in form, and sparsely to, more commonly, highly vesicular (Fig. 9B and C). The shapes of the coarse, ash-sized fragments vary from sickleshaped (concavo-convex) to cuspate, and bubble-wall shards to irregular jagged blocky forms (shard terminology of Pirsson, 1915 and Heiken, 1972) (Fig. 9A). These highly vesicular fragments are in framework support and show little or no evidence of compaction. Vesicles in the scoria fragments are spherical to oval in form (Figs. 9D and 10A), are infrequently elongated tubes, and comprise $<10 \%$ to $90 \%$ of the clasts by volume. Some vesicles are open and are surrounded by radiating and twisted sheaves of smectite clay minerals that replaced the original glass walls (Fig. 9D). Many vesicles are partially to completely lined with layers of light green smectite clay minerals growing radially inward to form amygdules (Figs. 9D and 10A and B). The centers of some vesicles are filled with sparry calcite and/or with scarce analcime.

Many scoria fragments contain scattered, aligned to randomly arranged microlites of albite-twinned plagioclase set in greenish birefringent to nearly isotropic smectite that replaced the glassy groundmass. Phenocrysts of plagioclase $\left(\mathrm{An}_{47}\right.$ to $\mathrm{An}_{64}$-calcic andesine to labradorite) and a few zeolite- and clay-filled pseudomorphs of some ferromagnesian mineral, probably pyroxene, occur in scoria fragments from the lower part of the volcanogenic unit (Fig. 10A).
Hole 467 Miocene tuffs are extensively diagenetically altered compared to Miocene tuffs from Sites 468 and 469. The original glass is replaced by green to nearly opaque smectite, clear isotropic analcime, and more rarely K-feldspar (Fig. 10A and C). These authigenic minerals that occur together as a suite or assemblage have replaced some scoria fragments; other scoria fragments are replaced by smectite only. In still other samples, smectite in association with analcime only or with $\mathrm{K}$-feldspar only is the replacement assemblage. $\mathrm{K}$-feldspar, when replacing glass between spherical vesicles, occurs as euhedral flattened rhombic crystals (Fig. 10D) or as anhedral masses of crystals, which, in abundance, create the light gray color of scoria clasts in slabbed cores. In a few samples, plagioclase is partially replaced by K-feldspar and/or calcite (with little or no analcime present).

Authigenic pyrite is present in tuffs as cubes filling pores or more commonly as a rind, lining the vesicles and surfaces of many smectite-altered lapilli and scoria shard fragments (Fig. 9A). Finely disseminated pyrite appears to replace completely the glass in some scoria fragments along with clay minerals to create dark opaque clasts (Fig. 10A). A few gypsum and large euhedral crystals of barite are present in the matrix and as pore fillings in vesicles of some volcanic rock fragments (Fig. 11A) in the lower part of the Miocene volcanogenic unit.

The matrix of tuffs in Hole 467 is greenish brown smectite clay, formed from diagenetic breakdown of glassy scoria shards (Fig. 9A). In some altered, fine ash, vitric tuff, this abundant matrix has obliterated the primary shard textures. Analcime occurs as vesiclefillings in scoria and as pore-fillings in the diagenetic clay matrix in altered scoriaceous tuffs. The analcime is, in turn, overgrown by sparry calcite crystals, suggesting a paragenetic sequence of alteration of glass to smectite clays, then filling of pore spaces with analcime, followed by precipitation of calcite crystals in remaining pores (Fig. 11B and C). The analcime occurs as euhedral trapezohedral crystals (Fig. 11D). Some tuffs in the lower part of the volcanic unit are completely cemented by a mosaic of sparry calcite. Calcite also occurs as rhombs with analcime, replacing the glass walls of some amygdaloidal scoria fragments (Fig. 10B).

\section{Pumiceous Lapilli Tuff and Volcanic Breccia}

Miocene pumiceous lapilli tuff forms the upper part of the density-graded volcanic breccia in Hole 469 (Core 33 , Section 1) and is interbedded with tuffaceous and volcanic sandstone in Hole 468B (26-1, 37-1, and 37-2). Light gray pumice comprises $60 \%$ to $80 \%$ of the lapilli tuff. Other components include nonvesicular perlitic glass, coarse ash-sized shards, volcanic rock fragments, and sand-sized mineral clasts (Fig. 12A).

Long-tube and short-tube (cellular) pumice (varieties after Fiske, 1969; and van der Lingen, 1973) are equally abundant in the lapilli tuff. These clasts are generally subangular to angular. Lapilli of short-tube pumice contain irregular to nearly spherical vesicles and a few phenocrysts of albite-twinned plagioclase and quartz 


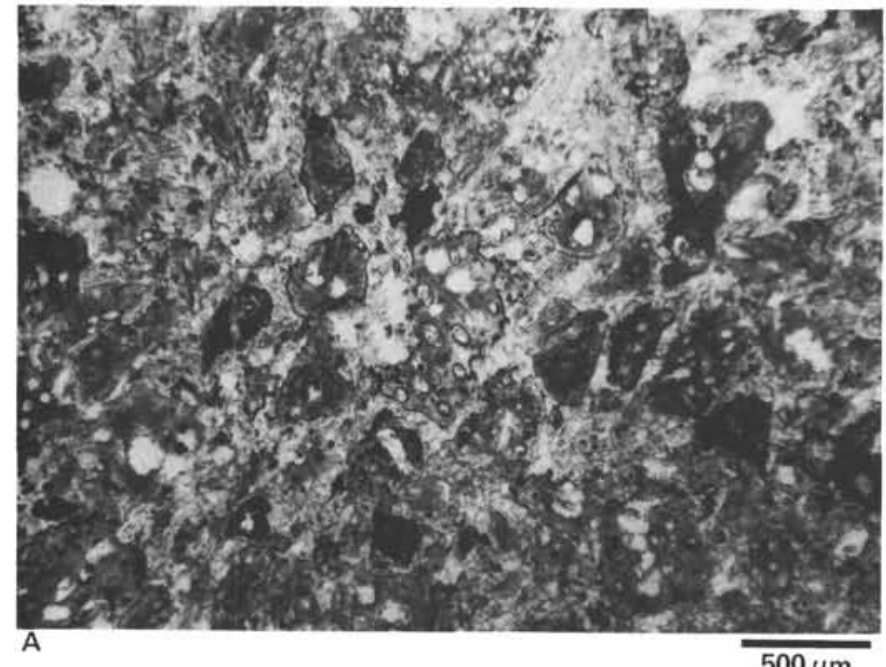

$500 \mu \mathrm{m}$
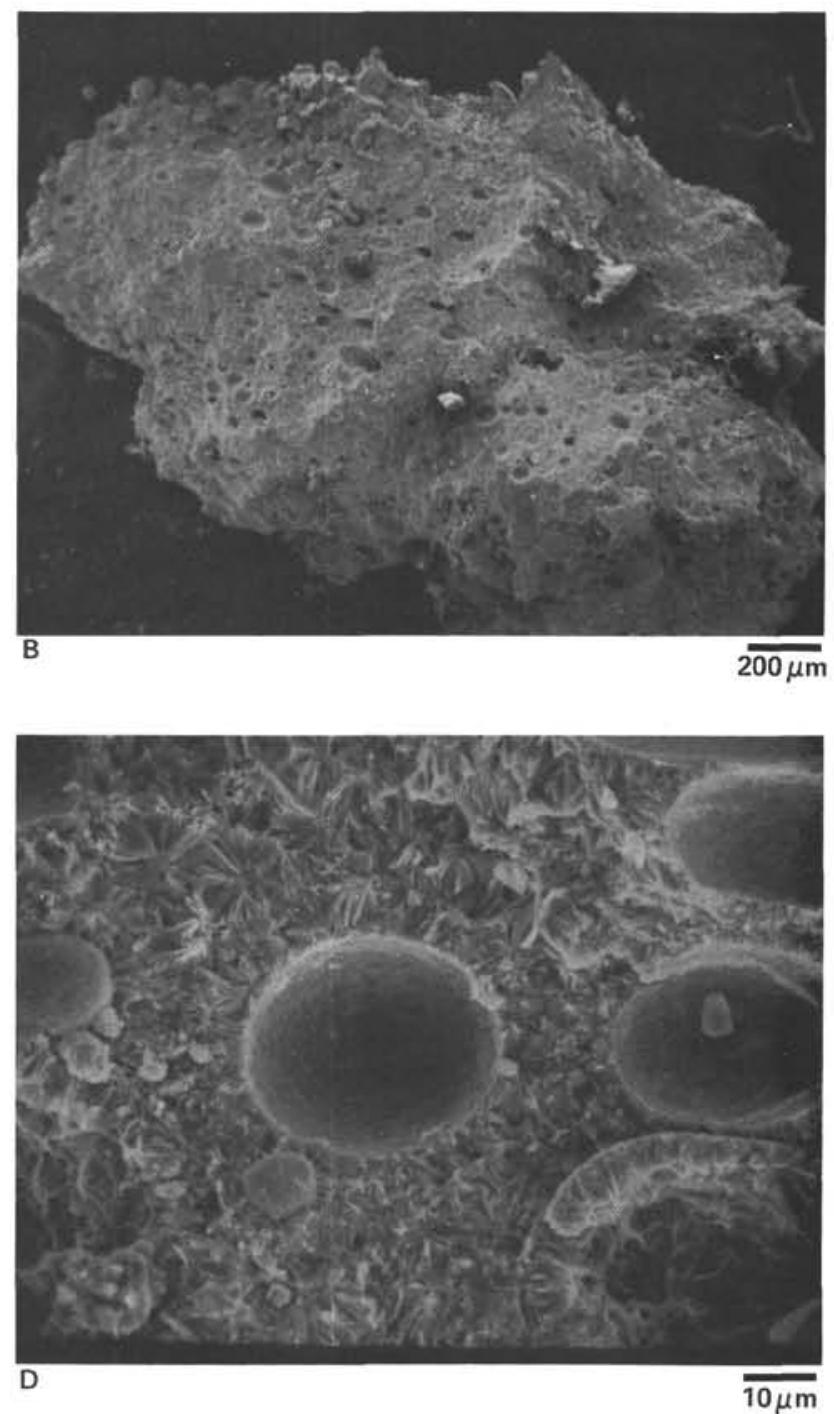

$\overline{10 \mu \mathrm{m}}$

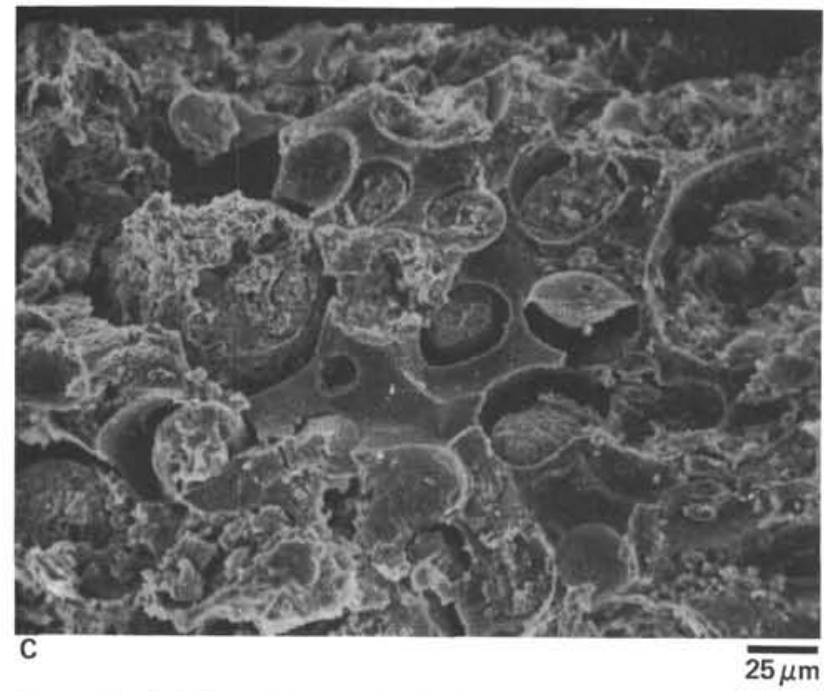

Figure 9. A. Photomicrograph of altered scoriaceous vitric tuff, Sample 467-79-1, 45-50 cm. (Note the irregular blocky scoria fragments with abundant round to oval vesicles. Pyrite forms the thin opaque rind on the scoria fragment in the center of the photograph. Plane-polarized light.) B. SEM micrograph of angular elongate vesicular lapilli-sized scoria clast. (Sample $467-81-1,18-20 \mathrm{~cm}$. Bar scale is $200 \mu \mathrm{m}$ long.) C. SEM micrograph showing typical vesicular surface of a lapilli-sized altered scoria fragment. (Spherical vesicles are filled with smectite clay minerals. Sample 467-79-2, 45-50 cm. Bar scale is $25 \mu \mathrm{m}$ long.) D. SEM micrograph of the surface of the lapilli-sized scoria clast in Figure $9 \mathrm{~B}$. (Note the radiating sheaves of smectite clays and open and partially filled spherical vesicles rimmed with smectite.)

(Fig. 12B). Both types of pumice show little or no compaction of the vesicles. Long-tube and short-tube pumice are colorless and relatively fresh; refractive indices average about 1.502 (e.g., Sample 468B-23,CC, $23-25 \mathrm{~cm}$ ). Glass with this refractive index contains about $71 \% \mathrm{SiO}_{2}$, which, with phenocryst mineralogy, suggests a rhyodacitic composition (Williams et al., 1954; Taylor, 1978). Initial stages of dissolution and hydration of the pumice are indicated by corroded or embayed vesicle walls under high SEM magnification (Fig. 12C and D). These diagenetic effects limit the accuracy of the present refractive index as an indicator of the composition of the original glass.

The color of fresh perlitic glass ranges from clear to dark brown. Perlitic glass occurs as subangular to subrounded fragments (Fig. 12A and B). These dense nonvesicular glass fragments are generally smaller than the vesicular, less dense pumice. The dark brown glass (black in cores) contains scattered plagioclase microlites, some with palagonite rims typical of basaltic glass or tachylyte (Honnorez, 1978). The very light brown to nearly colorless fresh perlitic glass has a refractive index of 1.514 (or about $65 \% \mathrm{SiO}_{2}=$ dacitic composition; Sample 468B-34-1, 90-94 cm).

Coarse ash-sized, bubble-wall shards are less abundant in the lapilli tuff and contain fewer but more spherical vesicles than the pumice lapilli. Commonly, the bubble-wall shards are replaced by clinoptilolite. Other volcanic clasts include pyroxene andesites with hyalopilitic, pilotaxitic, and glomeroporphyritic textures and vesicular basalts with intersertal texture. Nonvolcanic clasts include calcareous siltstone, volcanic sandstone, sand-sized quartz, plagioclase, augite, glauconitic pellets, and scarce hornblende. Vedder and 

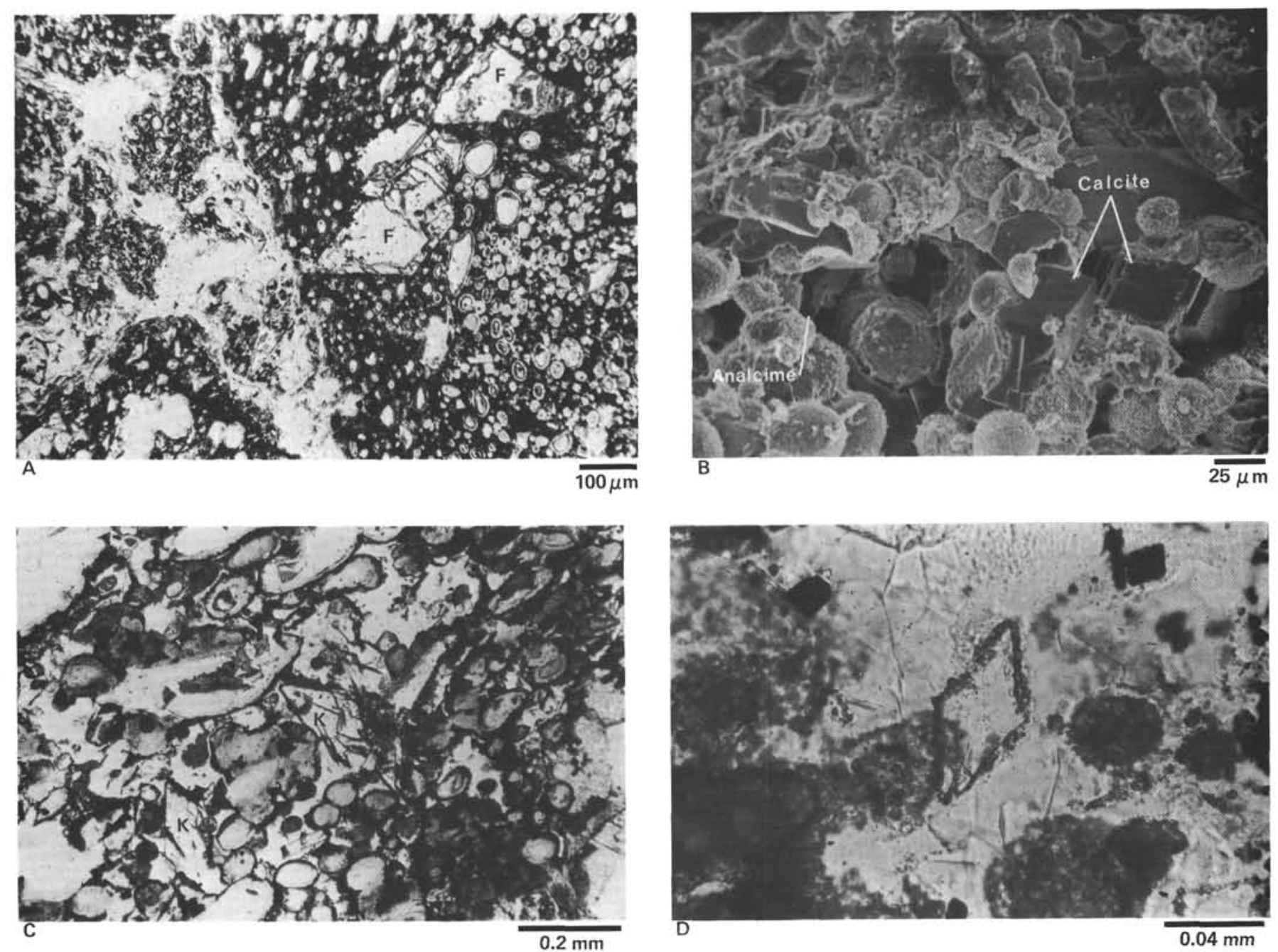

Figure 10. A. Photomicrograph of vesicular porphyritic lapilli that contains partial zeolite pseudomorphs of some ferromagnesian mineral (F). (Light-colored smectite clay minerals line the oval vesicles. Opaque groundmass is finely disseminated pyrite and clay minerals. Sample $467-82-1,15-18 \mathrm{~cm}$. Plane-polarized light.) B. SEM micrograph of an altered lapilli-sized scoria fragment. (The spheroidal bodies are amygdules of smectite clay cemented by rhombic crystals of calcite and trapezohedral crystals of analcime. Sample $467-80-2,54-56 \mathrm{~cm}$. Bar scale is $25 \mu \mathrm{m}$ long.) C. Photomicrograph of authigenic euhedral K-feldspar crystals $(\mathrm{K})$ replacing original glass in scoria fragment. (Vesicles are filled and partially lined with smectite clay minerals. Plane-polarized light. Sample 467-80-2, 20-24 cm.) D. Close-up of rhombic K-feldspar crystal and interlocking mosaic of clear K-feldspar crystals that replace glass of scoria fragments in Sample 467-81-1, 21-22 cm. (Dark, round vesicles are filled with diagenetic smectite clays. Plane-polarized light.)

others (this volume) also report gabbro, chert, epidote, and micaceous arkosic sandstone clasts in the pumiceous tuff-volcanic breccia in Hole 469 (Core 33, Section 1).

Fragments of shallow-water fossils are common in this pumiceous lapilli tuff-volcanic breccia and include bryozoans, echinoderm plates, pelecypods, and foraminifers (Fig. 13A). The matrix of this breccia consists of diatoms, sponge spicules, nannofossils, calcite crystals, and radiolarians in clay-size detritus (Fig. 13B). Grechin and others (this volume) report from X-ray diffraction analysis that opal-CT is a cement in this wellconsolidated breccia. Dolomite rhombs and pyrite occur in the matrix in some beds of volcanic breccia and pumiceous lapilli tuff (e.g., Sample 468B-34-1, 90-94 $\mathrm{cm})$.

Volcanic clasts in the breccia in Holes 468, 468B, and 469 are predominantly fragments of pyroxene andesitic to basaltic lava, perlitic glass, and blocky nonvesicular basaltic glass (tachylyte). Basaltic and andesitic clasts are nearly equally abundant in the volcanic breccias in Hole $468 \mathrm{~B}$, whereas basalt clasts are more abundant in the Miocene breccia in Hole 469. Textures in the pebblesized basaltic and andesitic clasts range from porphyritic, glomeroporphyritic, vitrophyric, hyalopilitic, and intersertal to diabasic. In the basaltic and andesitic clasts, oscillatory-zoned and albite-twinned plagioclase phenocrysts are generally calcic andesine to labradorite $\left(\mathrm{An}_{47}\right.$ to $\left.\mathrm{An}_{68}\right)$ in Site 468 breccias and are labradorite to bytownite $\left(\mathrm{An}_{60}\right.$ to $\left.\mathrm{An}_{72}\right)$ in Hole 469 breccias. Less common phenocrysts include augite, hypersthene, and minor olivine in intersertal basalt and diabase clasts. These phenocrysts occur in a groundmass of pale brown microlitic glass or in a groundmass composed of plagioclase and pyroxene microlites. The clear light brown isotropic glass that forms the groundmass of several of the 


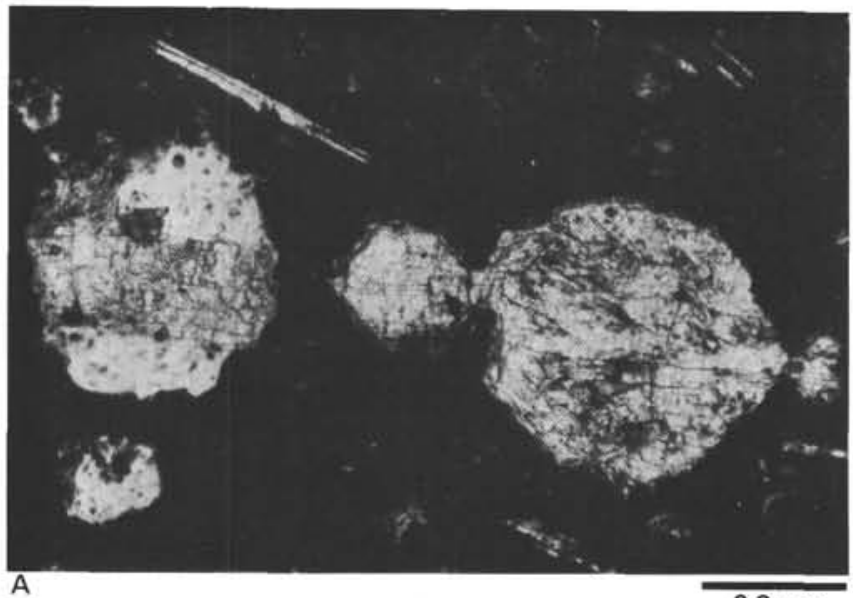

$0.2 \mathrm{~mm}$

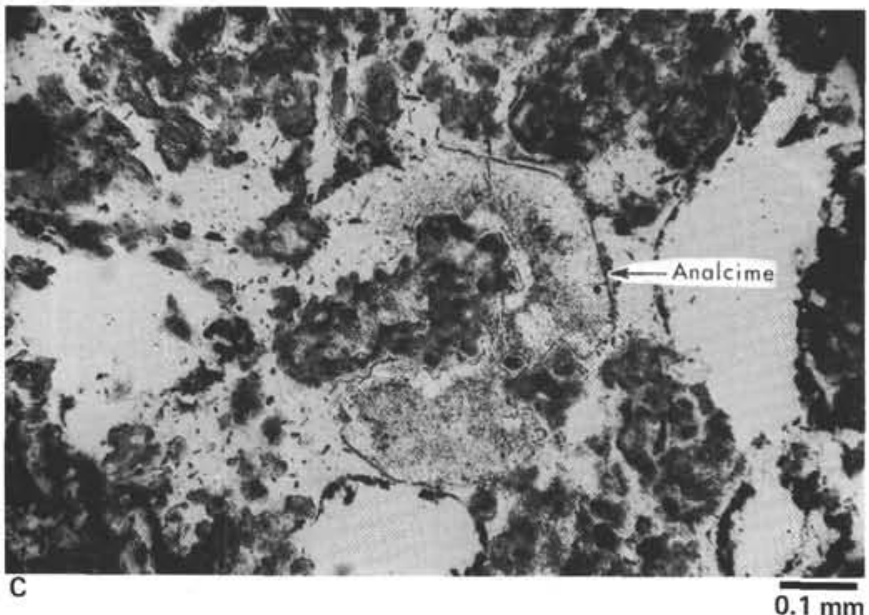

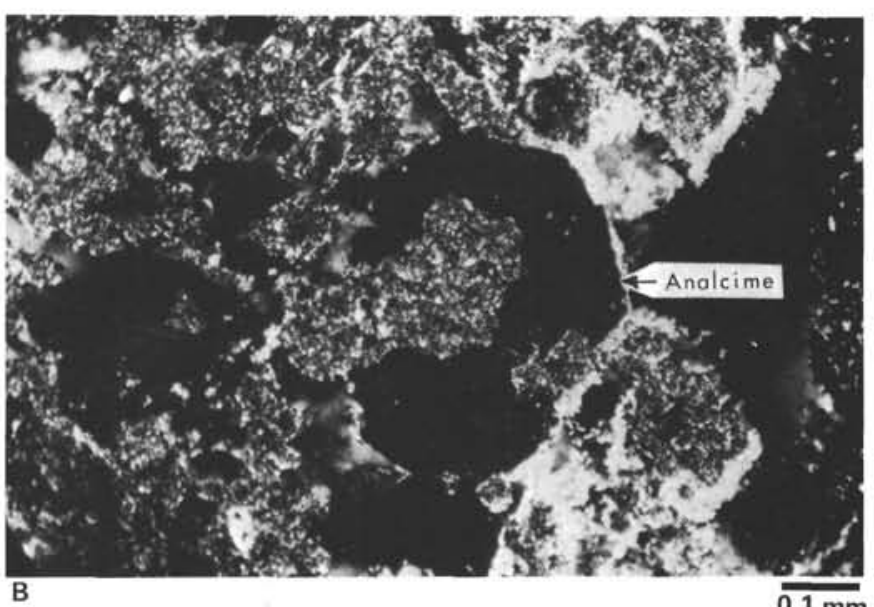

$0.1 \mathrm{~mm}$

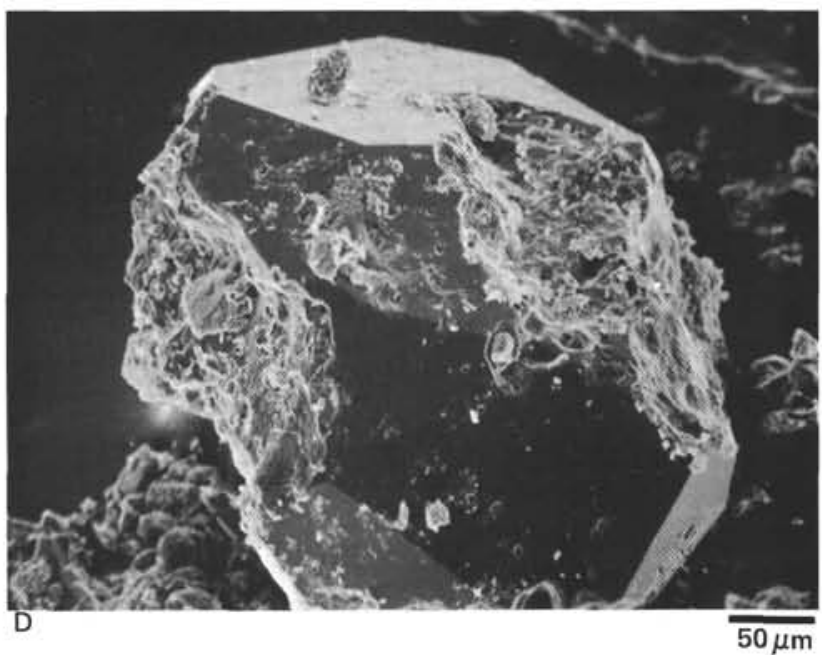

Figure 11. A. Barite with prismatic cleavage fills vesicles in clay-altered volcanic rock fragment. (Note plagioclase microlites. Sample 467-85-3, $88-91 \mathrm{~cm}$. Crossed nicols.) B. Photomicrograph of pore-filling sand-sized analcime crystal with sharp faces growing outward from a diagenetic smectite clay nucleus. (Altered fine ash tuff. Plane-polarized light. Sample 467-81-1, 22-24 cm.) C. Same as Figure 11B. (Analcime is isotropic under crossed nicols. Highly birefringent calcite overgrowths on the analcime crystal suggest that calcite followed analcime paragenetically. Sample 467-81-1, 22-24 cm.) D. SEM micrograph of trapezohedral analcime, hand-picked from Sample 467-80-2, $54-56 \mathrm{~cm}$. (Bar scale is $50 \mu \mathrm{m}$ long.)

vesicular pebbles with glomeroporphyritic texture has a refractive index of 1.544 , which corresponds to a silica content of about $55 \%$ (from Williams et al., 1954) or basaltic andesite composition (after Taylor, 1978) (Fig. 13C).

The basaltic andesite composition of the glomeroporphyritic clasts and silica content correspond fairly closely with the composition and silica content determined by chemical methods (see the chemical analysis section). This example illustrates that the phenocryst composition tends to indicate a more mafic composition of the lava fragments than the overall chemical composition and should not be used alone to determine the composition of the lava clasts. Some vesicles in the basaltic and andesitic clasts are lined with clinoptilolite or are filled with masses of green celadonite or sodiumharmotome. The celadonite amygdules may be the source of the "glauconite" pellets in the sand-sized fraction of some breccias and volcanic sandstone.
Nonvesicular dark to moderate brown tachylyte glass fragments are common in the volcanic breccias. The glass has a refractive index of 1.596 (Sample 469-33-1, 90-94 cm), which corresponds to a $\mathrm{SiO}_{2}$ content of about $47 \%$ (Williams et al., 1954) or a basaltic composition (Taylor, 1978). The tachylyte glass contains few microlites and plagioclase phenocrysts with quenched or skeletal textures. These nonvesicular fragments are blocky and angular with planar to gently curved surfaces typical of hyaloclastites formed from fragmentation of lavas by water (Heiken, 1972; Honnorez and Kirst, 1975). Some fragments are rimmed with palagonite or greenish celadonite/smectite clays. Zeolite, probably clinoptilolite, lines and partially fills a few palagonite rimmed voids that remained after dissolution of basaltic glass fragments. Typically, the center of the void is filled with sparry calcite. Sparry calcite also occurs as anhedral crystals replacing quartz grains and plagioclase phenocrysts in lava fragments or as veinlets 

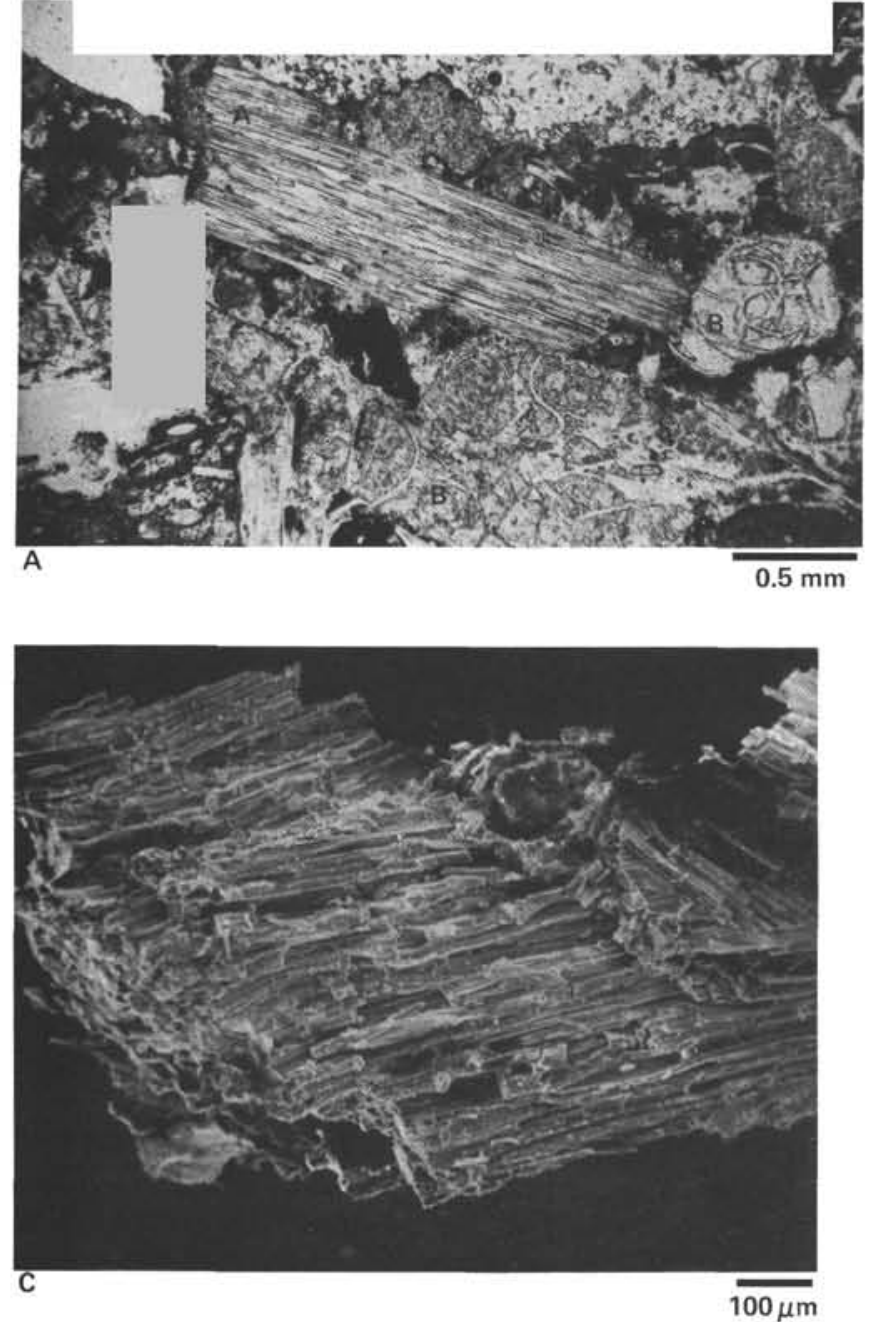
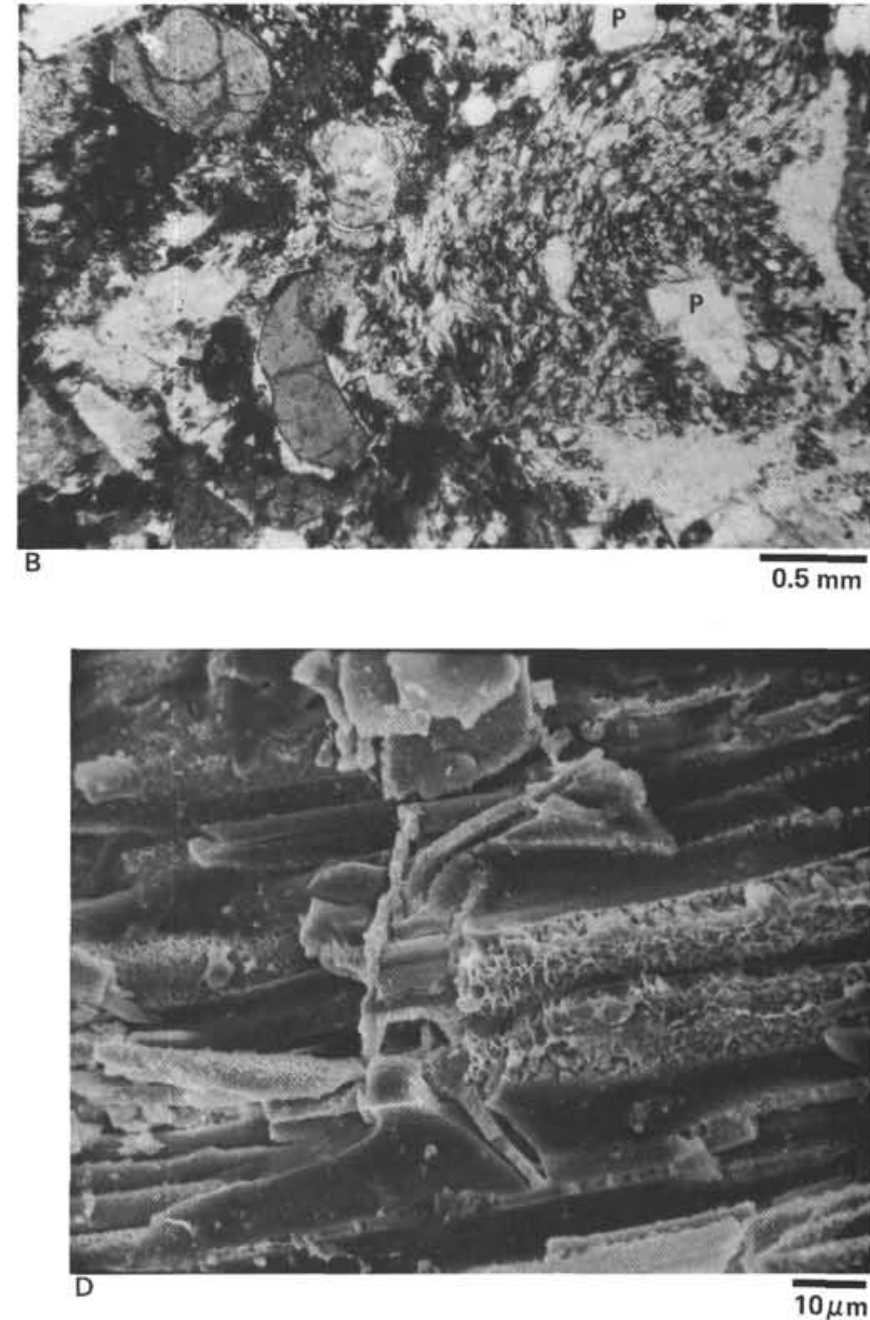

Figure 12. A. Unaltered long-tube pumice (A) and clear, nonvesicular perlitic glass (B) in pumiceous lapilli tuff. (Plane-polarized light. Sample 469-33-1, 30-33 cm.) B. Photomicrograph of cellular or short-tube pumice with phenocrysts of plagioclase (P) and rounded to subrounded, nonvesicular, brown perlitic glass (tachylyte) in pumiceous lapilli tuff. (Plane-polarized light. Sample 469-33-1, 19-21 cm.) C. SEM micrograph of long-tube pumice clast from pumiceous vitric tuff. (Sample 468B-37-1, 29-35 cm. Bar scale is $100 \mu \mathrm{m}$ long.) D. Enlarged view of long-tube pumice clast in Figure 12C. Note the irregular or corroded surface on some of the glassy walls, reflecting incipient dissolution and hydration of the pumice. (Sample 468B-37-1, 29-35 cm. Bar scale is $10 \mu \mathrm{m}$ long.)

in the matrix of Miocene volcanic breccias in Hole 468B (e.g., Sample 468B-34-1, 11-15 cm) and Hole 469.

Tuffaceous and volcanic sandstone interbeds between pumiceous lapilli tuffs in Hole $468 \mathrm{~B}$ contain less than $50 \%$ pyroclastic debris. The nonpyroclastic detritus consists mostly of coarse ash-sized crystals of quartz, oscillatory-zoned and albite-twinned plagioclase, andesitic and basaltic rock fragments, pyroxene, some sanidine, hornblende, and glauconitic grains. The heavy mineral fraction also includes magnetite, zircon, epidote, and traces of apatite, sphene, and rutile. The sand-sized grains are moderately well-sorted and are subangular to well-rounded, reflecting an earlier period of abrasion (Fig. 13D).

Biotics in these sandstones include foraminifers, diatoms, and sponge spicules. Some brown clay matrix occurs. The principal cements in the Miocene tuffaceous and volcanic sandstone, volcanic breccia, and lapilli tuff in Holes 468B and 469 are zeolites, mainly clinoptilolite, calcite in some cores, and dolomite rhombs in others. Clinoptilolite forms pore-filling aggregates of prismatic crystals (Figs. 13D and 14A).

\section{Unaltered Vitric Ashes and Altered Vitric Tuffs}

Unaltered to slightly altered Miocene, Pliocene, and Quaternary vitric ashes occur at Sites 470 and 472 and in the upper parts of Holes 467, 468, 469, 471, and 473 (Figs. 2A and B). Altered Miocene vitric tuffs occur in the lower parts of Holes 468, 469, 471, and 473. Smear slides and thin sections of 24 samples from all these sites show that the unaltered vitric ashes consist predominantly of fresh and clear to slightly altered bubble-wall and sickle-shaped or cuspate glass shards (Fig. 14B). Some ashes contain a small percentage of pumice lapilli (both short- and long-tube pumice), monocrystalline quartz, albite-twinned plagioclase, sanidine(?), and rare 

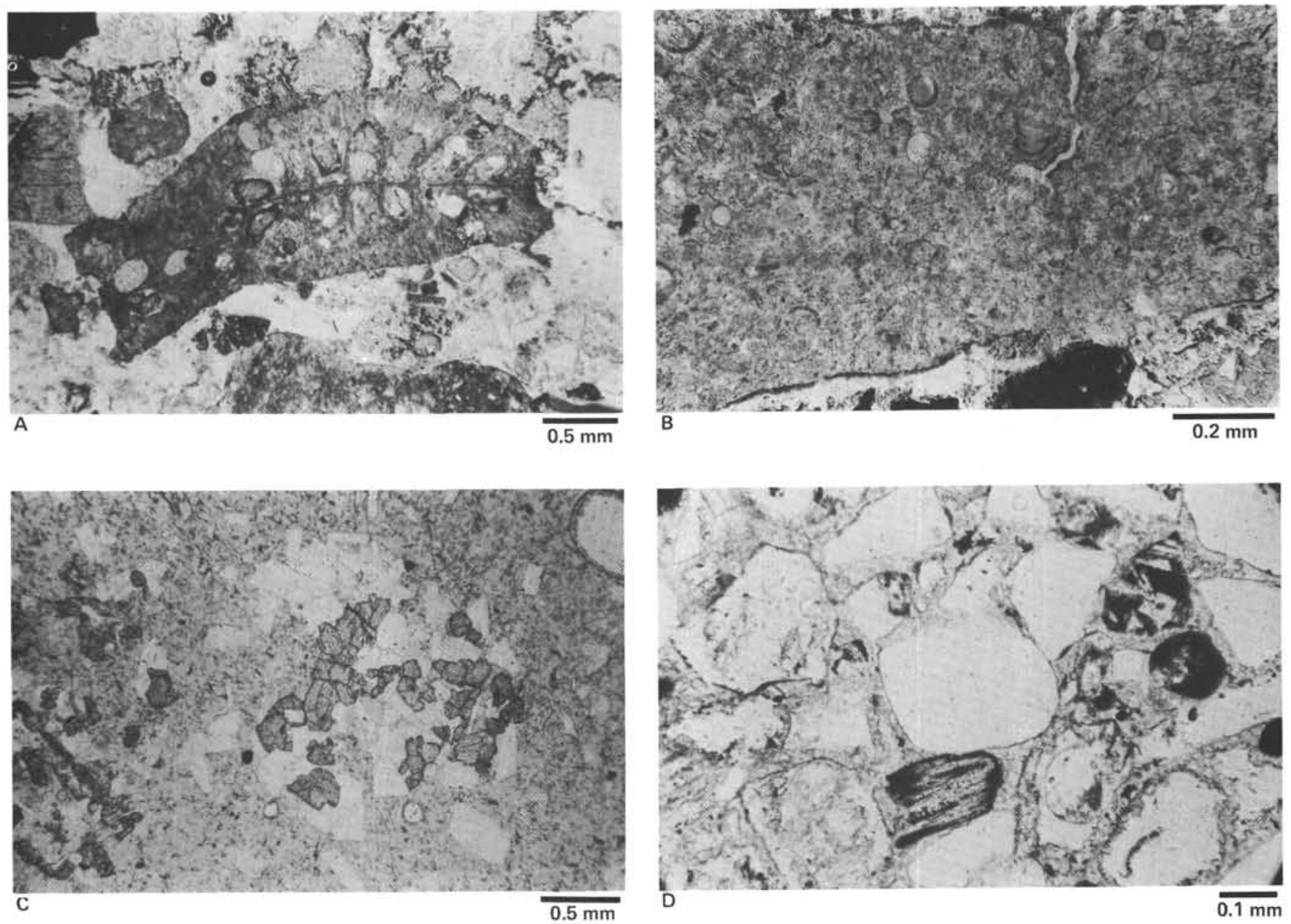

Figure 13. A. Photomicrograph of bryozoan in pumiceous lapilli tuff. (Plane-polarized light. Sample 469-33-1, 30-33 cm.) B. Photomicrograph of diatomaceous-spicule clay matrix in pumiceous lapilli tuff. (Plane-polarized light. Sample 469-33-1, 30-33 cm. Bar scale is $0.2 \mathrm{~mm}$ long.) C. Photomicrograph of glomeroporphyritic texture in basaltic andesite pebble, Sample 468B-34-1, 90-94 cm. (Light-colored phenocrysts are zoned labradorite $\left[\mathrm{An}_{68}-\mathrm{An}_{72}\right]$; darker phenocrysts are augite and hypersthene in a light brown glassy groundmass. Plane-polarized light.) $\mathrm{D}$. Photomicrograph of tuffaceous sandstone composed of subangular to well-rounded plagioclase, quartz, basalt, and pumice fragments cemented by prismatic crystals of the zeolite clinoptilolite. (Sample 468B-22-1, 2-6 cm. Plane-polarized light.)

tourmaline, biotite, and hornblende. Coccoliths, siliceous sponge spicules, opaque clay lumps, and finely disseminated authigenic pyrite also occur in a few ashes.

Refractive indices of unaltered clear glass shards in nine samples range from 1.496 to 1.518 . These refractive indices indicate a silica content of $73 \%$ to $64 \%$, which, with the quartz grains in the unaltered ashes, suggests a dacitic to rhyodacitic composition (Taylor, 1978). Chemical analyses of these unaltered vitric ashes show a lower $\mathrm{SiO}_{2}$ content $(55.7 \%$ to $63.3 \%$, Table 1) more typical of andesitic to dacitic composition. However, some bulk rock analyses probably included nonpyroclastic constituents, such as biotics, pyrite, and detrital clay minerals, and may not be totally representative of the initial composition of the glass shards.

A mixture of pale brown transparent shards and colorless shards occurs in two vitric ashes at Sites 470 and 471 . The refractive indices of these mixed colored glass shards are considerably higher than the average refractive index (1.509) determined for ashes at the other sites (e.g., R.I. $=1.532$ or $58 \% \mathrm{SiO}_{2}$ for Sample $471-5-4,116-117 \mathrm{~cm}$ and R.I. $=1.540$ or $56 \% \mathrm{SiO}_{2}$ for Sample 470-2-1, 123-124 cm). The higher refractive indices and lower $\mathrm{SiO}_{2}$ content indicate a more intermediate or andesitic composition for these two ashes. Chemical analysis of this ash bed from Hole 471 shows the same $\mathrm{SiO}_{2}$ content (Table 1).

Miocene altered vitric tuffs from the lower parts of Holes 468, 469, 471, and 473 (Fig. 2A and B) have generally the same pyroclastic composition as the unaltered silicic vitric ashes higher in the section. However, the bubble-wall and cuspate glass shards are partially to completely replaced by greenish smectite clay minerals, carbonates, pyrite, and zeolite (principally clinoptilolite). In some altered tuffs only outlines of the bubble-wall shards remain (Fig. 14C). The heavy mineral fraction in these tuffs consists of authigenic pyrite and some magnetite. Hornblende, zircon, pyroxene, and epidote are present in smaller quantities along with traces of apatite, muscovite, rutile, glaucophane (in 

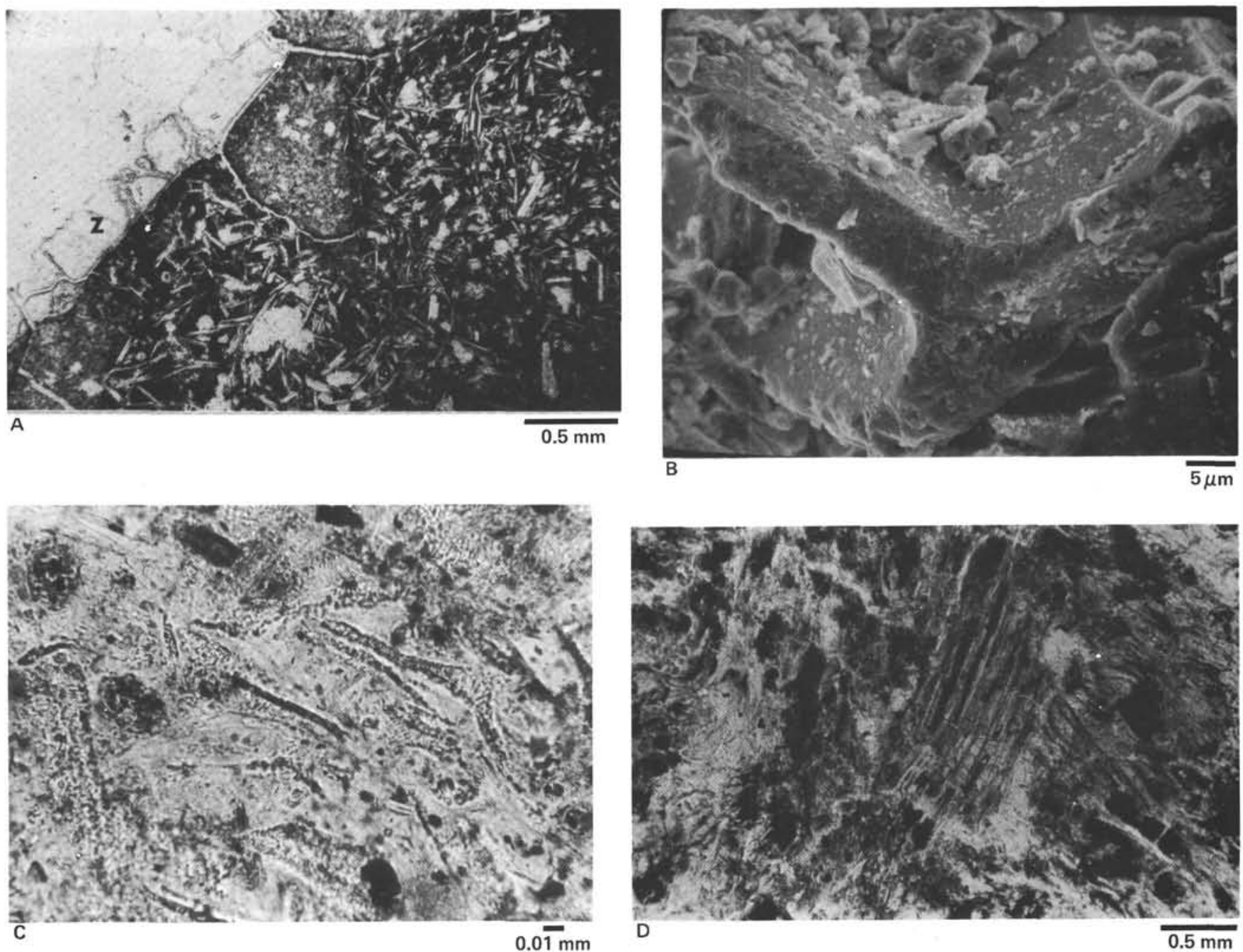

Figure 14. A. Photomicrograph of pore-filling zeolite clinoptilolite (Z) growing on a clay matrix and diktytaxitic basalt fragment in volcanic breccia, Sample 469-33-1, 97-100 cm. (Plane-polarized light.) B. SEM micrograph of bubble-wall rhyodacitic glass shard $(\mathrm{R} . \mathrm{I}$. $=1.500)$ with incipient clay platelets adhering to the surface. (Slightly altered Pliocene vitric ash. Sample 469-8-5, 5-7 $\mathrm{cm}$. Bar scale is $5 \mu \mathrm{m}$ long.) C. Photomicrograph of altered vitric tuff, showing glass shards partially to completely replaced by clays and zeolities. (Plane-polarized light. Bar scale is $0.01 \mathrm{~mm}$ long.) D. Photomicrograph of altered long-tube pumice in pumiceous vitric tuff. Opaque material infilling some pumice tubes is pyrite and an unidentified clay(?) or amorphous material. (Sample 469-36-1, 78-79 cm. Plane-polarized light.)

Sample 468B-23,CC, $23-25 \mathrm{~cm}$ ), and sphene. Biotite is an abundant accessory mineral in a 5 -cm-thick tuff in Hole 471-44-3, 35-50 cm.

Below the relatively unaltered pumice lapilli tuff-volcanic breccia unit in Hole 469 are two beds of altered vitric tuff separated by a silty claystone (Core 36; Fig. 2A). These tuffs differ from most altered vitric tuffs drilled in the California borderland and Baja California sites in that altered, coarse ash-sized pumice constitutes more than $90 \%$ of the rock (Fig. 14C). Altered longtube pumice (Sample 469-36-1, 78-79 $\mathrm{cm}$ ) and shorttube pumice (Sample 469-36,CC) is pale greenish brown to opaque. The glass has been extensively replaced by smectite clays. Vesicles are infilled with finely disseminated pyrite and/or with opaque to greenish amorphous material or clay(?), possibly smectite, which is white in reflected light (Fig. 14D). A clay matrix containing diatoms, radiolarians, and some foraminifers forms the minor nonglassy fraction of these tuffs. Further downsection in Core 37, vitric tuff consists of nonpumiceous, vesicular ash of altered bubble-wall shards and sparse quartz and plagioclase. The shards are clear to brownish in plane-polarized light, and many are replaced by calcite, zeolite, and opaque amorphous clay(?) material that first occurs in the pumiceous vitric tuffs in Core 36.

\section{CLAY MINERALOGY}

Smectites are the predominant clay mineral in the $<1-\mu \mathrm{m}$-size fraction of all analyzed samples from Holes 467 through 473 . Chlorite, mica, dehydrated halloysite, and mixed-iayer clays of various composition are present in subordinate amounts. SEM micrographs indicate that minor amorphous material may also occur. Identification of mixed-layer clay minerals was based on the work of V. A. Drits and B. A. Sakharov (1976). 
Table 1. Chemical composition of ashes and tuffs from Holes 467, 468, 468B, 469, 470, 471, and 473.

\begin{tabular}{|c|c|c|c|c|c|c|c|c|c|c|c|c|c|c|c|c|c|c|}
\hline \multirow{2}{*}{$\begin{array}{l}\text { Hole } \\
\text { Core-Section } \\
\text { Interval }(\mathrm{cm})\end{array}$} & \multicolumn{5}{|c|}{467} & \multirow{2}{*}{ 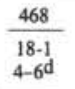 } & \multicolumn{3}{|c|}{$468 \mathrm{~B}$} & \multicolumn{2}{|c|}{469} & \multicolumn{2}{|c|}{470} & \multicolumn{3}{|c|}{471} & \multicolumn{2}{|c|}{473} \\
\hline & $\begin{array}{c}74-2 \\
96-100^{\mathrm{a}}\end{array}$ & $\begin{array}{c}74-2 \\
119-123^{a}\end{array}$ & $\begin{array}{c}80-2 \\
16-20^{\mathrm{b}}\end{array}$ & $\begin{array}{c}82-1 \\
118-121^{b}\end{array}$ & $\stackrel{84-1}{31-35^{c}}$ & & $\begin{array}{l}27-1 \\
6-8^{x}\end{array}$ & $\begin{array}{c}27-1 \\
10-12^{x}\end{array}$ & $\begin{array}{c}27-1 \\
17-20 c\end{array}$ & $\begin{array}{c}8-5 \\
40-44 f\end{array}$ & $\begin{array}{c}36-1 \\
77-788\end{array}$ & $21^{3-3}-23^{\mathrm{h}}$ & $\underset{97-98 f}{5-2}$ & $\stackrel{5-4}{114-116^{f}}$ & $\begin{array}{l}36-1 \\
91-93^{i}\end{array}$ & $\begin{array}{c}44-3 \\
40-42^{\mathrm{i}}\end{array}$ & $\begin{array}{c}16-3 \\
40-42^{f}\end{array}$ & $\begin{array}{c}26-2 \\
32-36^{j}\end{array}$ \\
\hline $\mathrm{SiO}_{2}$ & 40.95 & 41.76 & 41.58 & 42.76 & 45.61 & 58.44 & 56.90 & 55.40 & $\$ 2.72$ & 55.70 & 53.75 & 57.39 & 63.29 & 57.11 & 53.00 & 53.69 & 58.86 & 57.12 \\
\hline $\mathrm{TiO}_{2}$ & 2.47 & 2.48 & 2.21 & 2.13 & 2.12 & 0.53 & 1.90 & 1.85 & 1.83 & 0.34 & 0.46 & 0.46 & 0.45 & 0.70 & 0.40 & 0.27 & 0.23 & 0.47 \\
\hline $\mathrm{Al}_{2} \mathrm{O}_{3}$ & 16.75 & 17.40 & 15.15 & 15.82 & 16.89 & 14.11 & 25.20 & 24.20 & 22.18 & 10.20 & 12.98 & 14.54 & 12.53 & 14.86 & 15.44 & 17.83 & 13.34 & 13.56 \\
\hline $\mathrm{Fe}_{2} \mathrm{O}_{3}$ & 10.56 & 10.69 & 2.53 & 2.82 & 3.56 & 2.73 & 1.90 & 2.30 & 2.37 & 13.90 & 5.29 & 3.98 & 4.18 & 4.06 & 3.17 & 3.32 & 4.62 & 3.96 \\
\hline $\mathrm{FeO}$ & 0.50 & 0.43 & 4.83 & 4.54 & 3.86 & 1.85 & - & - & 0.64 & 0.57 & 0.97 & 1.20 & 1.24 & 1.97 & 0.70 & 0.74 & 1.04 & 1.36 \\
\hline $\mathrm{MnO}$ & 0.10 & 0.07 & 0.10 & 0.10 & 0.04 & 0.06 & - & - & 0.02 & 0.03 & 0.15 & 0.17 & 0.06 & 0.09 & 0.01 & 0.01 & 0.03 & 0.13 \\
\hline $\mathrm{MgO}$ & 1.59 & 2.62 & 10.52 & 10.43 & 6.44 & 1.69 & 0.40 & 0.50 & 1.63 & 0.61 & 4.78 & 1.36 & 0.95 & 1.64 & 5.24 & 3.59 & 0.73 & 3.99 \\
\hline $\mathrm{CaO}$ & 3.60 & 2.35 & 4.58 & 4.01 & 1.79 & 4.91 & 8.00 & 8.10 & 8.65 & 1.51 & 1.59 & 1.13 & 1.82 & 3.64 & 0.83 & 1.11 & 0.84 & 1.68 \\
\hline $\mathrm{Na}_{2} \mathrm{O}$ & 1.84 & 1.84 & 1.84 & 2.34 & 7.39 & 4.57 & 4.90 & 4.90 & 5.07 & 3.53 & 2.70 & 7.61 & 5.30 & 5.18 & 3.06 & 2.70 & 4.60 & 3.83 \\
\hline $\mathrm{K}_{2} \mathrm{O}$ & 0.31 & 0.24 & 2.10 & 1.66 & 0.72 & 2.87 & 1.55 & 1.80 & 1.13 & 3.29 & 0.89 & 4.58 & 3.72 & 2.87 & 0.43 & 0.31 & 3.72 & 2.44 \\
\hline $\mathrm{H}_{2} \mathrm{O}^{+}$ & 4.34 & 4.11 & 5.67 & 4.46 & 6.71 & 4.37 & - & - & 0.99 & 2.35 & 5.73 & 4.63 & 4.32 & 3.41 & 5.48 & 6.60 & 4.93 & 3.93 \\
\hline $\mathrm{H}_{2} \mathrm{O}^{-}$ & 9.26 & 9.11 & 6.23 & 6.87 & 3.95 & 1.39 & - & - & 1.57 & 0.83 & 8.12 & 1.04 & 0.64 & 0.80 & 10.91 & 9.16 & 1.94 & 5.35 \\
\hline $\mathrm{P}_{2} \mathrm{O}_{5}$ & 0.05 & 0.04 & 0.90 & 0.51 & 0.11 & 0.12 & - & - & 0.83 & 0.02 & 0.04 & 0.04 & 0.07 & 0.20 & 0.03 & 0.02 & 0.02 & 0.14 \\
\hline $\mathrm{CO}_{2}$ & 0.00 & 0.00 & 0.95 & 0.85 & 0.00 & 1.00 & - & - & 0.00 & 0.00 & 0.50 & 0.00 & 0.00 & 0.20 & 0.12 & 0.13 & 0.00 & 0.00 \\
\hline C & 0.00 & 0.00 & 0.00 & 0.00 & 0.00 & 0.00 & - & - & 0.00 & 0.52 & 0.59 & 0.33 & 0.11 & 0.08 & 0.18 & 0.00 & 0.29 & 0.20 \\
\hline $\mathrm{SO}_{3}$ & 3.93 & 2.90 & 0.47 & 0.20 & 0.34 & 0.33 & - & - & - & 2.84 & 0.24 & 0.22 & 0.10 & 1.31 & 0.00 & 0.00 & 4.05 & 0.52 \\
\hline $\mathrm{Cl}^{\circ}$ & 0.14 & 0.14 & - & 0.07 & 0.35 & 0.89 & - & - & - & 0.29 & 0.90 & 1.55 & 1.12 & 1.83 & 0.75 & 0.5 & 0.23 & 1.34 \\
\hline $\mathrm{s}$ & 6.36 & 6.72 & - & 0.10 & 0.76 & 0.79 & - & - & - & 6.90 & 0.27 & 0.03 & 0.25 & 0.57 & 0.12 & 0.15 & 0.64 & 0.31 \\
\hline Total & 102.75 & 102.90 & 99.66 & 99.67 & 100.63 & 100.65 & & & 99.63 & 103.44 & 99.95 & 100.26 & 100.15 & 100.52 & 100.02 & 100.19 & 100.11 & 100.33 \\
\hline $\begin{array}{l}\mathrm{O}=\mathrm{S} \\
\mathrm{O}=\mathrm{Cl}_{2}\end{array}$ & $\begin{array}{l}3.18 \\
0.03\end{array}$ & $\begin{array}{l}3.36 \\
0.03\end{array}$ & $\underline{-}$ & $\begin{array}{l}0.05 \\
0.01\end{array}$ & $\begin{array}{l}0.38 \\
0.08\end{array}$ & $\begin{array}{l}0.40 \\
0.20\end{array}$ & $z$ & $\underline{-}$ & $\overline{-}$ & $\begin{array}{l}3.45 \\
0.06\end{array}$ & $\begin{array}{l}0.13 \\
0.20\end{array}$ & $\begin{array}{l}0.01 \\
0.35\end{array}$ & $\begin{array}{l}0.13 \\
0.25\end{array}$ & $\begin{array}{l}0.28 \\
0.41\end{array}$ & $\begin{array}{l}0.06 \\
0.17\end{array}$ & $\begin{array}{l}0.08 \\
0.13\end{array}$ & $\begin{array}{l}0.32 \\
0.05\end{array}$ & $\begin{array}{l}0.16 \\
0.30\end{array}$ \\
\hline Total & 99.54 & 99.51 & 99.66 & 99.61 & 100.17 & 100.05 & 100.75 & 99.05 & 99.63 & 99.92 & 99.62 & 99.90 & 99.77 & 99.83 & 99.79 & 99.98 & 99.74 & 99.87 \\
\hline
\end{tabular}

a Very altered scoriaceous vitric tuff.

b Altered scoriaceous lapilli tuff.

c Altered scoriaceous vitric tuff.

Unaltered pumiceous lapilli and ash.

e Pebble of pyroxene basaltic andesite from breccia.

1 Unaltered vitric ash.

${ }_{\mathrm{h}}$ Altered pumiceous vitric tuff.

h Pumice fragment.

i Altered vitric tuff.

$\mathrm{x}$ Chemical analysis of basaltic andesite pebble using atomic absorption, $\mathrm{X}$-ray fluorescence, and visible light spectrophotometry techniques at Department of

Geology, Oregon State University, performed by E. M. Taylor and R. Lightfoot.

\section{Altered Scoriaceous Tuff}

Seven samples of scoriaceous tuff from Site 467 were analyzed. Whole-rock chemical analyses were performed on five samples (Table 1), and the chemical composition of the $\langle 1-\mu \mathrm{m}$-size fraction of two samples were determined (Table 2). Representative diffractograms are presented in Figure 15.

Except in samples from Core 74, the clay-size fraction of scoriaceous tuffs at Site 467 consists predominantly of two varieties of smectite; Al-bearing dioctahedral smectite (beidellite) and trioctahedral high magnesium smectite (saponite). Dioctahedral species are characterized by an (060) d-spacing of $1.49 \mathrm{~A}$; trioctahedral species are defined by an (060) d-spacing of 1.53 $\AA$ (Fig. 15). Chemical analysis of the $<1-\mu \mathrm{m}$ fraction of Sample 467-80-2, 16-20 cm (Table 2) also shows a high $\mathrm{MgO}$ content, probably reflecting the trioctahedral smectite. Lattice parameters $a$ and $b$ of the unit cells of dioctahedral and trioctahedral smectites were determined with the electron diffraction method (Table 3). In addition, the ratio of the intensities of the $(060)$ reflections helped us to determine that the relative proportions of dioctahedral to trioctahedral phases in several samples vary from about $1: 1$ to $1: 4$.

On the basis of the diffractograms of air-dried samples and of samples that were heated at $550^{\circ} \mathrm{C}$, the trioctahedral and dioctahedral clays were further divided into two groups. One group has an (001) d-spacing of 12.7 to $12.8 \AA$ air-dried, which expands to 17.7 $\AA$ after glycerine treatment and collapses to about 9.9 $\AA$ after heating, characteristic of common smectites (Samples 467-82-1, 114-118 cm; 467-83-3, 83-85 cm; and $467-84-1,31-35 \mathrm{~cm}$ ). Interlayers of smectites in
Table 2. Chemical composition of the $<1-\mu \mathrm{m}$-size fraction of altered tuffs, Leg 63 .

\begin{tabular}{|c|c|c|c|c|c|}
\hline \multirow{2}{*}{$\begin{array}{l}\text { Hole } \\
\text { Core-Section } \\
\text { Interval }(\mathrm{cm})\end{array}$} & \multicolumn{2}{|c|}{467} & \multirow{2}{*}{$\begin{array}{c}469 \\
36-1 \\
77-78^{c}\end{array}$} & \multirow{2}{*}{$\begin{array}{c}471 \\
\begin{array}{c}44-3 \\
40-42^{d}\end{array}\end{array}$} & \multirow{2}{*}{$\begin{array}{r}473 \\
26-2 \\
32-36\end{array}$} \\
\hline & $\begin{array}{c}74-2 \\
96-100^{a}\end{array}$ & $\begin{array}{c}80-2 \\
16-20^{b}\end{array}$ & & & \\
\hline $\mathrm{SiO}_{2}$ & 48.72 & 39.53 & 51.97 & 55.60 & 54.98 \\
\hline $\mathrm{TiO}_{2}$ & 2.58 & 1.78 & 0.56 & 0.23 & 0.30 \\
\hline $\mathrm{Al}_{2} \mathrm{O}_{3}$ & 19.29 & 14.82 & 13.24 & 18.19 & 15.08 \\
\hline $\mathrm{Fe}_{2} \mathrm{O}_{3}$ & 5.85 & 5.64 & 5.26 & 3.39 & 5.23 \\
\hline $\mathrm{FeO}$ & 0.24 & 3.81 & 1.01 & 0.80 & 1.44 \\
\hline $\mathrm{MnO}$ & 0.02 & 0.11 & 0.13 & 0.00 & 0.08 \\
\hline $\mathrm{MgO}$ & 3.35 & 13.05 & 5.81 & 3.40 & 5.64 \\
\hline $\mathrm{CaO}$ & 1.66 & 2.77 & 1.68 & 1.60 & 1.12 \\
\hline $\mathrm{Na}_{2} \mathrm{O}$ & 0.08 & 0.79 & 0.67 & 0.51 & 0.95 \\
\hline $\mathrm{K}_{2} \mathrm{O}$ & 0.22 & 0.52 & 0.80 & 0.22 & 2.16 \\
\hline $\mathrm{CO}_{2}$ & 0.00 & - & - & 0.26 & 0.00 \\
\hline $\mathrm{P}_{2} \mathrm{O}_{5}$ & 0.05 & - & - & 0.01 & - \\
\hline $\mathrm{SO}_{3}$ & 1.21 & - & - & 0.00 & 0.00 \\
\hline $\mathrm{S}$ & 0.42 & - & - & 0.04 & - \\
\hline L.O.I. & 16.04 & 16.68 & 18.98 & 15.92 & 13.01 \\
\hline Total & 99.73 & 99.50 & 100.11 & 100.17 & 99.99 \\
\hline $\mathrm{O}=\mathrm{S}$ & 0.21 & - & - & 0.02 & - \\
\hline Total & 99.52 & 99.50 & 100.11 & 100.15 & 99.99 \\
\hline
\end{tabular}

Note: L.O.I. = loss on ignition.

a Very altered scoriaceous tuff.

b Altered scoriaceous tuff.

c Altered pumiceous tuff.

d Altered vitric tuff.

these samples are probably filled with exchangeable $\mathrm{Na}$ cations. In the other group, with an (001) d-spacing of 14.2 to $14.8 \AA$ air-dried, the interlayers of smectites are probably filled mainly with $\mathrm{Mg}$ cations (Samples $467-80-2,16-20 \mathrm{~cm}$ and $467-82-1,118-120 \mathrm{~cm})$. These 


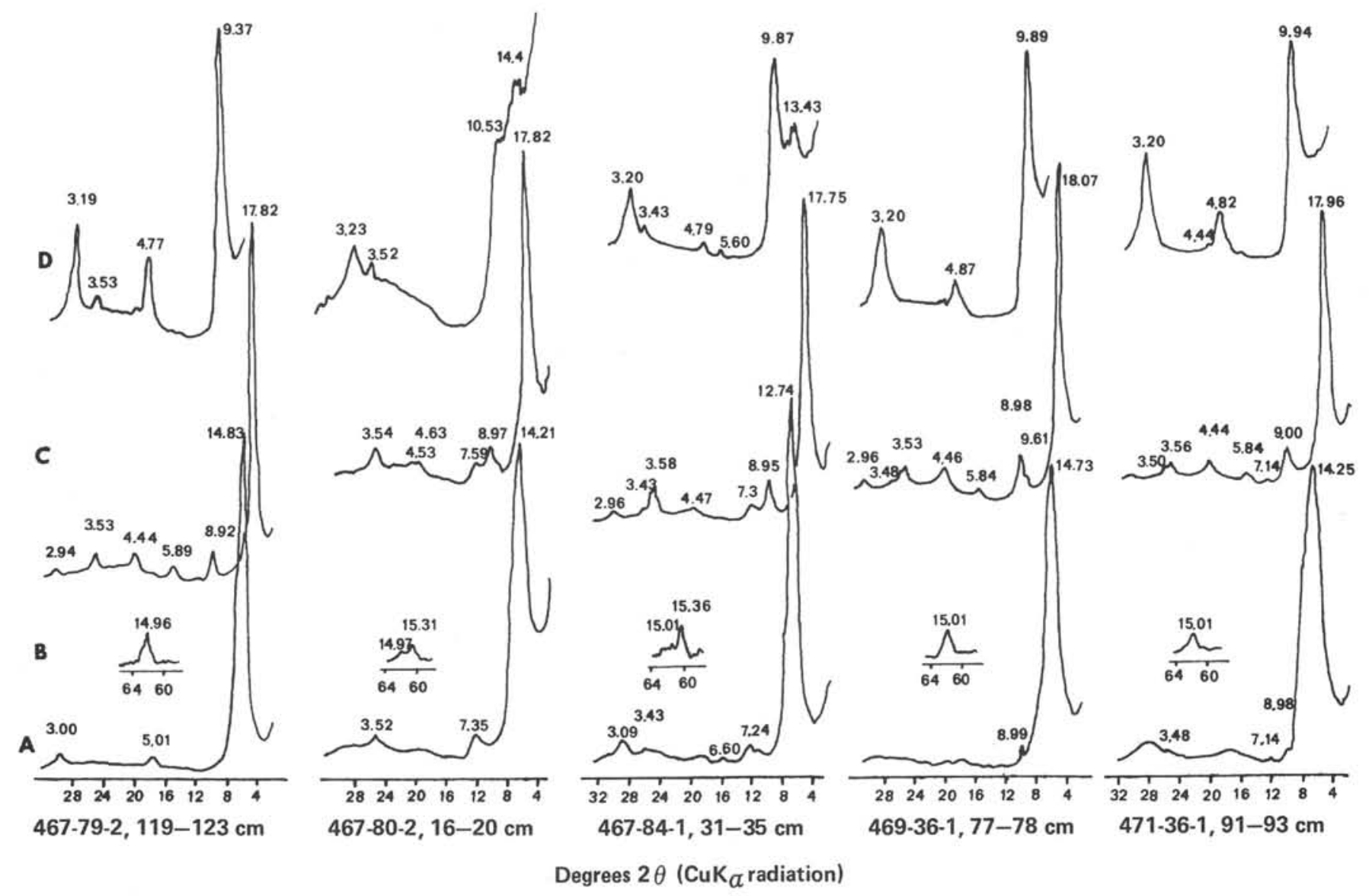

Figure 15. Typical diffractograms of the $<1-\mu \mathrm{m}$ fraction from altered tuffs. (A. Oriented air-dried sample; B. 060 reflection from randomly oriented air-dried sample; C. oriented sample saturated with glycerine; D. oriented sample heated at $550^{\circ} \mathrm{C}$.)

Table 3. Lattice parameters, $a$ and $b$, of the unit cells and the intensity ratio, $I$, of $(060)$ reflections of dioctahedral and trioctahedral smectites in altered tuffs, Site 467, Leg 63.

\begin{tabular}{lcccc}
\hline $\begin{array}{l}\text { Core-Section } \\
\text { Interval }(\mathrm{cm})\end{array}$ & $\begin{array}{c}82-1 \\
118-120\end{array}$ & $\begin{array}{c}82-1 \\
114-118\end{array}$ & $83-85$ & $\begin{array}{c}84-1 \\
31-35\end{array}$ \\
\hline$a_{\mathrm{d}}$ & 5.20 & 5.19 & 5.19 & 5.19 \\
$b_{\mathrm{d}}$ & 9.00 & 8.99 & 8.99 & 8.99 \\
$a_{\mathrm{t}}$ & 5.31 & 5.30 & 5.31 & 5.32 \\
$b_{\mathrm{t}}$ & 9.19 & 9.18 & 9.19 & 9.20 \\
$I_{\mathrm{t}}: I_{\mathrm{d}}$ & $1: 1$ & $1: 1$ & $1: 1$ & $1: 4$ \\
\hline
\end{tabular}

Note: Subscripts $\mathrm{d}$ and $\mathrm{t}$ denote dioctahedral and trioctahedral varieties of smectite.

minerals swell with addition of glycerine, like smectites do, but do not collapse when dehydrated. After heating at $550^{\circ} \mathrm{C}$, a wide reflection with d-spacing of 10 to $14 \AA$ was recorded, typical of chloritic intergrades (Fig. 15). Hydroxy polymers of $\mathrm{Mg}, \mathrm{Al}, \mathrm{Fe}$, and others that prevent compression of the crystal lattice during heating probably occupy interspaces in the smectites of this group. This suggests an initial stage of chloritization of the smectites.

In addition to smectites, there is a mixed-layer chlorite-smectite in some samples. The mixed-layer clay was identified on diffractograms of heated samples by
12.9 to $13.5 \AA$ reflections and by 7.3 to $7.7 \AA$ reflections for samples saturated with glycerine. Alternatively, the 7.3 to $7.7 \AA$ peaks that were destroyed upon heating to $550^{\circ} \mathrm{C}$ could reflect minor amounts of dehydrated halloysite or kaolinite. Micalike interlayers appear to be present in the smectite of only one sample (467-83-3, 83-85 cm).

In summary, most of the clay-size fraction of the scoriaceous tuffs characteristically contains a mixture of dioctahedral and trioctahedral smectites, some of which may have been affected by the process of chloritization.

The smectite mineral and chemical compositions of the tuff in Core 74 differ from the other tuffs in Hole 467 (Tables 1 and 2 and Fig. 15). The single (060) reflection with d-spacing of $1.496 \AA$ indicates that only dioctahedral smectite is present in this altered tuff. Further X-ray study of samples prepared by the GreeneKelly method (Greene-Kelly, 1953) showed that after saturation in $3 \mathrm{~N} \mathrm{LiCl}$ solution, the (001) d-spacing was $12.3 \AA$ (Fig. 16). Heating of the Li-saturated sample at $250^{\circ} \mathrm{C}$ for $3 \mathrm{hr}$. resulted in decrease of the d-spacing to $11.3 \AA$; after heating at $300^{\circ} \mathrm{C}$, the (001) d-spacing collapsed to $9.8 \AA$. With subsequent saturation with glycol, the sample that had been heated at $300^{\circ} \mathrm{C}$ produced a series of reflections with d-spacings of 16.3, $9.00,5.53,4.38$, and $3.35 \AA$. These results indicate that this dioctahedral smectite is probably a mixed-layer bei- 


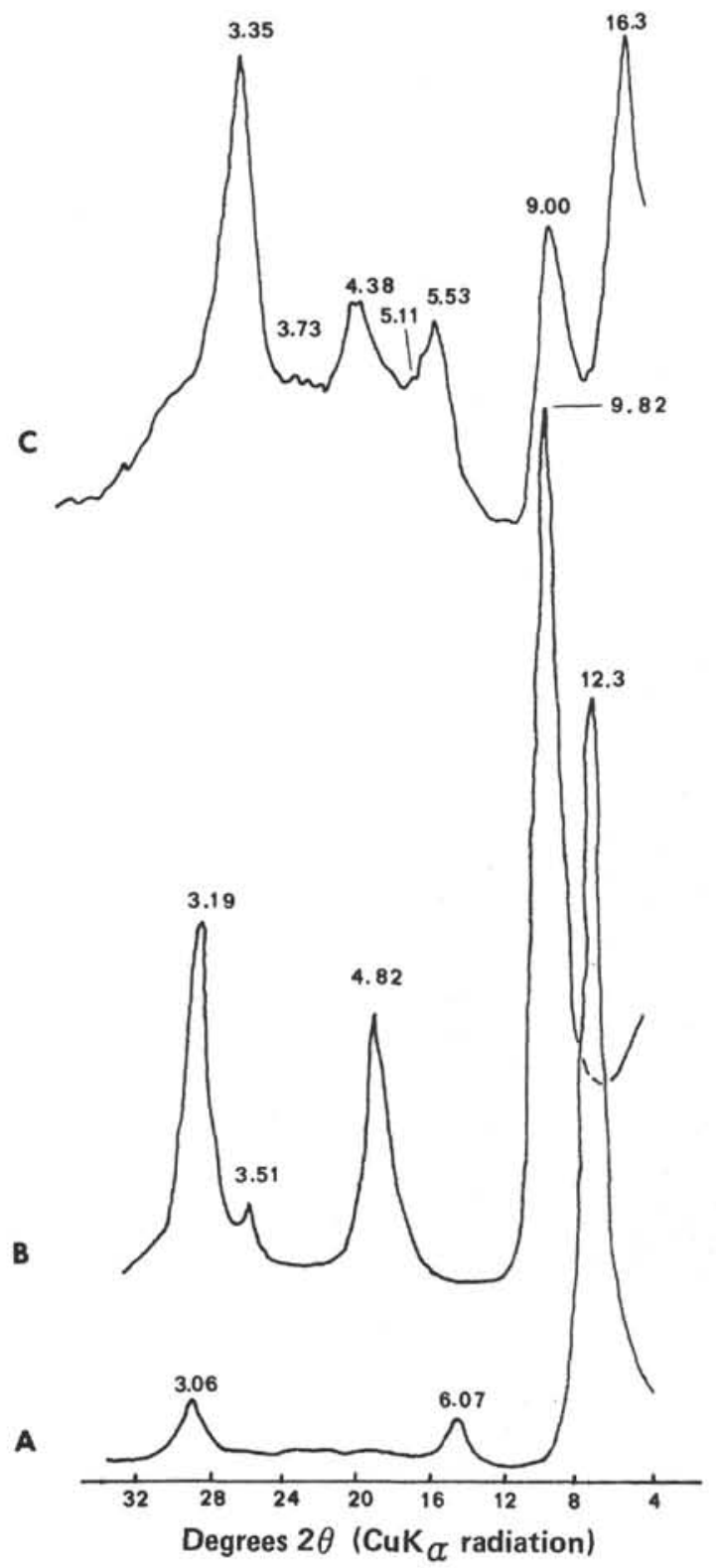

Figure 16. Diffractograms of Sample 467-74-2, 119-123 cm treated by the Greene-Kelly method (Greene-Kelly, 1953). (A. Saturated with $\mathrm{LiCl}$; B. saturated with $\mathrm{LiCl}$ and heated at $300^{\circ} \mathrm{C}$; C. saturated with $\mathrm{LiCl}$, heated at $300^{\circ} \mathrm{C}$, and saturated with glycol.)

dellite-montmorillonite. We are aware that other studies have shown that the Greene-Kelly method may not be a consistent test for mixed layer beidellite-smectite ( $R$. Glasmann, personal communication, 1981).

We calculated an approximate structural formula for the beidellite-montmorillonite in the tuff bed in Core 74 using the chemical analysis of the $<1-\mu \mathrm{m}$ fraction (Table 2). Estimations of the proportions of different ionic components were made on the basis of equality of cation valences to $\mathrm{O}_{10}(\mathrm{OH})_{2}$ anion composition of $2: 1$ layers. Carbon dioxide was assumed to be bound into $\mathrm{CaCO}_{3}, \mathrm{SO}_{3}$ bound into $\mathrm{CaSO}_{4}, \mathrm{P}_{2} \mathrm{O}_{5}$ bound into
$\mathrm{Ca}_{3}\left(\mathrm{PO}_{4}\right)$, and $\mathrm{S}$ bound into $\mathrm{FeS}_{2}$. If it is assumed that $\mathrm{Ti}$ forms a part of the smectite structure, the formula is:

$$
\begin{gathered}
\left\{\mathrm{K}_{0.02} \mathrm{Na}_{0.01} \mathrm{Ca}_{0.06} \mathrm{Mg}_{0.16}\right\}\left(\mathrm{Si}_{3.63} \mathrm{Al}_{0.37}\right) \\
\left(\mathrm{Al}_{1.33} \mathrm{Fe}^{3}{ }_{0.03}^{+} \mathrm{Fe}^{2+}{ }_{0.01} \mathrm{Ti}_{0.14} \mathrm{Mg}_{0.22}\right) \mathrm{O}_{10}(\mathrm{OH})_{2}
\end{gathered}
$$

If, however, $\mathrm{Ti}$ is represented by free oxides in the rock, then the chemical composition of this mineral is:

$$
\begin{aligned}
& \left\{\mathrm{K}_{0.02} \mathrm{Na}_{0.01} \mathrm{Ca}_{0.06} \mathrm{Mg}_{0.17}\right\}\left(\mathrm{Si}_{3.73} \mathrm{Al}_{0.27}\right) \\
& \left(\mathrm{Al}_{1.47} \mathrm{Fe}_{0.30}^{3+} \mathrm{Fe}_{0.01}^{2+} \mathrm{Mg}_{0.22}\right) \mathrm{O}_{10}(\mathrm{OH})_{2}
\end{aligned}
$$

The former chemical composition shows that the overall negative charge of the 2:1 layers mostly results from substitution of $\mathrm{Si}$ by $\mathrm{Al}$ in the tetrahedra. In the latter formula, the negative charge is almost equally divided between the tetrahedral and octahedral sheets of the 2:1 layers. Consequently, the second chemical formula better represents the structure of the mixed-layer mineral beidellite-montmorillonite found in this tuff. We recognize that there may be other impurities (such as gels and iron oxides) in the $<1-\mu \mathrm{m}$ fraction, which could affect the allocation of cations and anions to the chemical structural formula. The formulae are only meant to show an ideal case.

\section{Altered Pumiceous Tuff and Volcanic Breccia and Sandstone}

Seven samples of altered pumiceous vitric tuff and associated volcanic breccia and sandstone from Holes $468,468 \mathrm{~B}$, and 469 were studied. The $<1-\mu \mathrm{m}$ fraction of altered pumiceous vitric tuffs (Samples 469-36-1, $77-78 \mathrm{~cm}$ and $469-38-1,32-36 \mathrm{~cm}$ ) consists of one smectite species (Fig. 15). In thin section, these samples contain little or no contamination by nonpyroclastic terrigenous material, and chemical analyses can be assumed to be fairly representative of the smectite composition.

Complete major oxide analyses of a whole-rock sample and of the $<1-\mu \mathrm{m}$ fraction were made for one pumiceous vitric tuff (Sample 469-36-1, 77-78 cm; Tables 1 and 2). There was such a small amount of the $<1-\mu \mathrm{m}$ fraction that the $\mathrm{CO}_{2}, \mathrm{P}_{2} \mathrm{O}_{5}, \mathrm{SO}_{3}$, and $\mathrm{S}$ contents could not be determined. By using the percentage of these components in the whole-rock sample and assuming that a certain percentage of the cations are bound up in salts and sulphides, we derived a tentative chemical formula of the smectite. The resulting structural formula is:

$$
\begin{gathered}
\left\{\mathrm{Ca}_{0.07} \mathrm{~K}_{0.08} \mathrm{Na}_{0.10} \mathrm{Mg}_{0.15}\right\}\left(\mathrm{Si}_{3.93} \mathrm{Al}_{0.07}\right) \\
\left(\mathrm{Al}_{1.10} \mathrm{Fe}^{3}{ }_{0.29}{ }^{2} \mathrm{Fe}_{0.06}^{2+} \mathrm{Ti}_{0.03} \mathrm{Mg}_{0.52}\right) \mathrm{O}_{10}(\mathrm{OH})_{2}
\end{gathered}
$$

From this composition, it follows that there is practically no substitution of $\mathrm{Si}$ by $\mathrm{Al}$ in the tetrahedral sites of the $2: 1$ layers and that the entire negative charge is 
localized in the octahedral layers. Therefore the smectite in the altered pumiceous vitric tuff of Hole 469 is dioctahedral montmorillonite. Noteworthy is a rather high charge of the $2: 1$ layers of 0.62 . The $(060) \mathrm{d}$-spacings are larger than $1.50 \AA$, which are probably due to a relatively high percentage of $\mathrm{Mg}$ and $\mathrm{Fe}^{3+}$.

The influence of a terrigenous source is obvious in diffractograms of other pumiceous vitric tuffs (Samples $469-29, \mathrm{CC}, 0-6 \mathrm{~cm}$ and 469-35-1, 49-52 cm), which contain, in addition to diagenetic smectite, detrital chlorite/ kaolinite, and mica peaks.

The positions and intensities of the peaks in diffractograms of the $<1-\mu \mathrm{m}$ fraction of four samples from Hole 468B (volcanic breccia, tuffaceous sandstone, and epiclastic pumiceous lapilli tuff) closely resemble the diffraction patterns of the altered pumiceous vitric tuff (Sample 469-36-1, 77-78 cm) pictured in Figure 15. The main clay-sized component of these Hole 468B samples is finely dispersed smectite. In contrast to the smectite in the Hole 469 samples, the smectite in the Hole 468B samples probably contains small amounts (up to 20\%) of unexpanded micaceous layers in its structure. Furthermore, the 15.2 to $15.5 \AA \mathrm{d}$-spacing in a diffractogram of an air-dried sample suggests that exchangeable divalent cations are present in interlayer positions of the smectite. The relatively low intensity of the $4.82 \AA$ peak (compared to the reflections with d-spacings of 9.98 and $3.21 \AA$ in a diffractogram of a heated sample) may be due to a larger number of $\mathrm{Fe}$ cations in the octahedral layers than in Sample 469-36-1, 77-78 cm.

An appreciable amount of chlorite occurs in the volcaniclastic sandstone (Samples 468B-26-1, 72-76 cm and 468B-26-1, 42-46 cm) and traces of chlorite were identified in epiclastic pumiceous lapilli tuff (Samples 468$37-2,19-26 \mathrm{~cm}$ and $468-34-1,60-73 \mathrm{~cm}$ ).

No detailed investigation of the green glauconite pellets in the epiclastic pumiceous lapilli tuff and volcaniclastic sandstone has yet been done. However, preliminary X-ray study of Sample 469-35-1, 49-52 cm shows that these green pellets are a mixture of two mineralogical phases: smectite (nontronite) and glauconite-celadonite.

\section{Altered Vitric Tuff}

Four samples of altered vitric tuff (471-36-1, 91-93 $\mathrm{cm}$; 471-44-3, 40-42 cm; 473-26-2, 32-36 cm; and 473$16-3,40-42 \mathrm{~cm}$ ) were analyzed. The main component of the clay fraction $(<1 \mu \mathrm{m})$ of altered vitric tuffs is finely dispersed dioctahedral smectite. The (060) d-spacing varies from 1.498 to $1.501 \AA$. These tuffs consist almost entirely of clay-altered glass shards. Assuming that the clay-size fraction consists of only one smectite species, the structural chemical formula (on the basis of the chemical analysis of Sample 471-44-3, 40-42 cm-Table 2) is:

$$
\begin{gathered}
\left\{\mathrm{K}_{0.02} \mathrm{Na}_{0.07} \mathrm{Ca}_{0.10} \mathrm{Mg}_{0.06}\right\}\left(\mathrm{Si}_{3.94} \mathrm{Al}_{0.06}\right) \\
\left(\mathrm{Al}_{1.46} \mathrm{Fe}_{0.18}^{3+} \mathrm{Fe}_{0.05}^{2+} \mathrm{Ti}_{0.01} \mathrm{Mn}_{0.01} \mathrm{Mg}_{0.30}\right) \mathrm{O}_{10}(\mathrm{OH})_{2}
\end{gathered}
$$

This formula shows that in the tetrahedral positions there is little substitution of $\mathrm{Si}$ by $\mathrm{Al}$ and the entire nega- tive charge of the 2:1 layers is a result of divalent $\mathrm{Mg}$ or $\mathrm{Fe}$ cations in the octahedral layers. This smectite is a typical dioctahedral montmorillonite. The relatively high intensity of the $(002)$ reflection with d-spacing of 4.82 to $4.9 \AA$ in diffractograms of all the heated samples further suggests that these smectites are an $\mathrm{Al}$ montmorillonite. Besides smectite in Sample 473-26-2, $32-36 \mathrm{~cm}$, other $(001)$ diffraction peaks suggest that there is a small amount of mica in Sample 473-26-2, $32-36 \mathrm{~cm}$ and traces of chlorite in Sample 471-36-1, $91-93 \mathrm{~cm}$. These clays are probably detrital in origin because these tuffs, in cores, show bioturbation with the adjacent claystones.

In summary, both the altered pumiceous tuff and the altered vitric tuff are characterized by ferruginous dioctahedral montmorillonite (nontronite). Chlorite and mica are present only in tuff and volcanic sandstone that contain an obvious admixture of terrigenous (nonpyroclastic) material.

\section{ZEOLITES AND K-FELDSPAR}

Authigenic zeolites are common in all the volcanogenic rocks of Sites $467,468,469,471$, and 473 . X-ray diffraction supplemented by thin section analysis and SEM study (see the Petrography section) distinguished two zeolite species. One belongs to the heulandite group and is represented most probably by clinoptilolite; the other is analcime. Authigenic K-feldspar occurs only in the scoriaceous tuff in Hole 467. Representative diffractograms of these two zeolite minerals and K-feldspar are presented in Figure 17.

We separated the two zeolites and K-feldspar (in the silt- and sand-size fractions) by using heavy liquids of different specific gravities. Clinoptilolite is the major mineral component in the 2.1 to $2.2 \mathrm{~g} / \mathrm{cm}^{3}$ density fraction. This zeolite also occurs in the clay-size fraction, appearing as a small $8.9 \AA$ peak in diffractograms of samples prepared for clay mineral analysis (e.g., Sample 469-36-1, 77-78 cm; Fig. 15). Analcime is abundant in the 2.2 to $2.3 \mathrm{~g} / \mathrm{cm}^{3}$ density fraction, and $\mathrm{K}$-feldspar forms much of the 2.5 to $2.6 \mathrm{~g} / \mathrm{cm}^{3}$ density fraction.

Diffractograms of the density-separated K-feldspar grains indicate that they are sanidine (Fig. 17C). Using the methodology and nomenclature of Barth (1969), diffraction patterns show that K-feldspar in Sample $467-80-2,16-20 \mathrm{~cm}$ is a high sanidine, containing mostly. potassium in the crystal structure $(\Delta \mathrm{p}=0, \Delta \mathrm{z}=0.06$, $\mathrm{Al}_{\mathrm{T}_{1}}=26, \mathrm{Al}_{\mathrm{T}_{2}}=24$ ). Sample $467-82-1,114-118 \mathrm{~cm}$ contains low sanidine (orthoclase) with appreciable potassium as well as sodium in the crystal structure $(\Delta \mathrm{p}=$ $0, \Delta \mathrm{z}=0.16, \mathrm{Al}_{\mathrm{T}_{1}}=29, \mathrm{Al}_{\mathrm{T}_{2}}=21$ ).

From X-ray data, thin section petrography, and SEM study, we recognized different mineralogic associations of authigenic zeolites, K-feldspar, and smectite minerals in scoriaceous tuff, pumiceous tuff, volcanic breccia and sandstone, and altered vitric tuff.

\section{Altered Scoriaceous Tuff}

Miocene scoriaceous tuff from Hole 467 contains analcime and $\mathrm{K}$-feldspar. Both minerals replace volcanic glass and occur as pore fillings. K-feldspar also partly replaces some plagioclase microlites. 

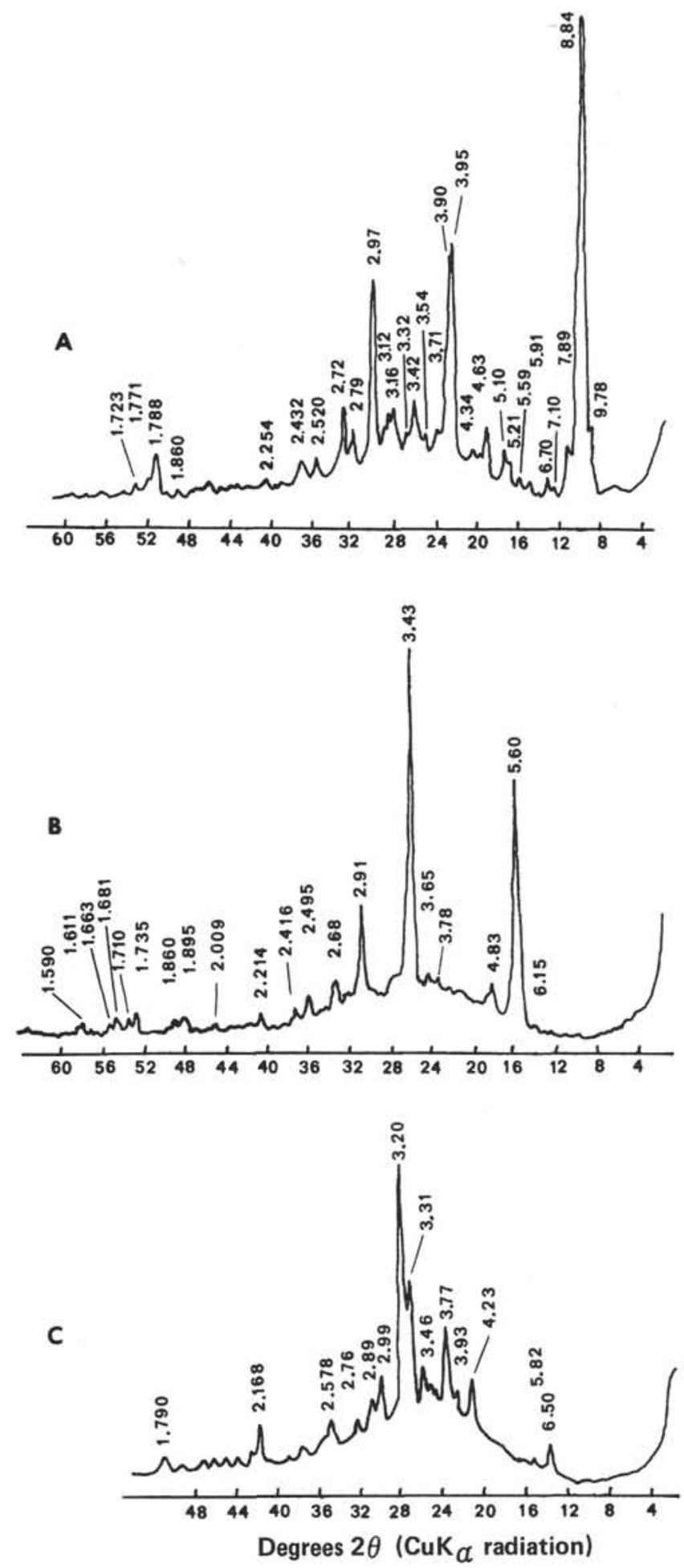

Figure 17. Diffractograms of clinoptilolite, analcime, and K-feldspar from the 0.1 - to $0.25-\mathrm{mm}$ size fraction. (A. Clinoptilolite, Sample $468 \mathrm{~B}-37-2,19-26 \mathrm{~cm}, 2.1$ to $2.2 \mathrm{~g} / \mathrm{cm}^{3}$ density fraction; B. analcime, Sample $467-80-2,16-20 \mathrm{~cm}, 2.2$ to $2.3 \mathrm{~g} / \mathrm{cm}^{3}$ density fraction; C. K-feldspar, Sample 467-80-2, $16-20 \mathrm{~cm}, 2.5$ to 2.6 $\mathrm{g} / \mathrm{cm}^{3}$ density fraction.)

Much of the analcime in Hole 467 is a cement (e.g., in Sample 467-84-1, 31-35 cm) occurring as trapezohedral crystals growing into pore spaces. Dioctahedral and trioctahedral smectites, some of which contain chloritic intergrades, are the main associated clay minerals.
Authigenic K-feldspar is a distinctive alteration product of some vesicular ash and lapilli in Hole 467, although smectite clays are the dominant diagenetic phase replacing most scoria fragments. In order to substantiate the optical identification of K-feldspar and to determine its structural state, we hand-picked light gray vesicular clasts from Sample 467-80-2, 20-24 cm and ground them in a mortar with acetone. We photographed the samples with a Debye-Scherrer powder camera using nickel-filtered $\mathrm{CuK}_{\alpha}$ radiation. Wright (1968) developed an empirical relationship between certain X-ray diffraction peaks ( $2 \theta$ values) and the a, b, c crystallographic axes of K-feldspar. This relationship can be applied to determine the structural state of a feldspar and, thereby, identify the type of K-feldspar present. For our sample, the $2 \theta$ values for the (201), (060), and $(\overline{2} 04)$ are $21.01^{\circ}, 41.59^{\circ}$, and $50.88^{\circ}$, respectively. These $2 \theta$ values, when plotted on Wright's figure 3 , indicate that the $\mathrm{K}$-feldspar in this sample is high sanidine. Another test to determine the structural state of K-feldspars was presented by Goldsmith and Laves (1954), who used the amount of splitting of the (131) reflection into a (131) and $(1 \overline{3} 1)$ pair as a measure of the triclinicity of the K-feldspar. Because the (131) reflection of our sample is a single peak (i.e., there is no split), the triclinicity is zero, and the symmetry of the mineral is monoclinic, which is the symmetry of high sanidine K-feldspar.

\section{Altered Pumiceous Tuff and Volcanic Sandstone}

Clinoptilolite and minor analcime replace volcanic glass, shards, and pumice and volcanic rock fragments in epiclastic Miocene pumiceous tuffs from Holes 468, $468 \mathrm{~B}$, and 469 . These zeolite minerals also occur as pore-filling cement. Clinoptilolite forms an appreciable part of the cement in Miocene tuffaceous and volcanic sandstones at these two sites as well. Analcime occurs discontinuously around the margins of some plagioclase crystals or fills fractures in these crystals. The associated diagenetic clay in the altered pumiceous tuff is ferruginous dioctahedral montmorillonite.

\section{Altered Vitric Tuff}

Altered vitric tuff contains a diagenetic mineral association similar to the suite in altered pumiceous tuff in Holes 468, 468B, and 469. These authigenic minerals are principally clinoptilolite with a small amount of analcime(?) as indicated by thin section analysis. The main diagenetic clay mineral associated with these zeolites in altered vitric tuff at Sites 468 through 473 is ferruginous dioctahedral smectite with a small amount of micaceous interlayers. This smectite clay mineral replaces glass shards and forms much of the diagenetic matrix in the altered vitric tuff.

\section{CHEMISTRY}

The results of whole-rock chemical analyses of tuff, vitric ash, and volcanic breccia pebbles are presented in Table 1. Ferric iron content $\left(\mathrm{Fe}_{2} \mathrm{O}_{3}\right)$ was calculated as the difference between total iron and ferrous iron $(\mathrm{FeO})$. Because pyrite does not decompose during the analytical procedure, ferrous iron in the pyrite is in- 
cluded as part of $\mathrm{Fe}_{2} \mathrm{O}_{3}$. In cases where the sulfur content was measured, it was not difficult to estimate the $\mathrm{FeS}_{2}$ content.

\section{Scoriaceous Tuff}

Chemical analyses show that scoriaceous tuff from Hole 467 differs in composition from tuffs and ashes at all other sites. All scoriaceous tuffs have a low $\mathrm{SiO}_{2}$ content that does not exceed $50 \%$ after recalculation without water. These tuffs also are low in total alkalis $(2-4 \%)$. An unusually high $\mathrm{Na}_{2} \mathrm{O}$ content $(7.39 \%)$ in Sample $467-84-1,31-35 \mathrm{~cm}$ is probably related to the abundance of analcime in the cement of this tuff. The high $\mathrm{TiO}_{2}$ content $(>2 \%)$ and low value of the $\mathrm{SiO}_{2}$ / $\mathrm{Al}_{2} \mathrm{O}_{3}$ ratio (2.4-2.8) also distinguish scoriaceous tuff from the pumiceous and vitric tuffs and vitric ashes from the other sites.

Estimation of the initial composition of these extensively altered scoriaceous tuffs by bulk chemical analysis is difficult because of the inclusion of minor nonpyroclastic components (e.g., biotics) in the whole-rock samples and because of the amount of pore-water migration of elements that probably occurred during alteration of the tuff in this porous open system. However, the $\mathrm{TiO}_{2}$ content can be useful in reconstructing the original composition because titanium is usually the least mobile element in secondary alteration changes. The relatively high $\mathrm{TiO}_{2}$ content in Hole 467 tuffs is similar in abundance to that analyzed in recent basaltic ashes reported by Heiken (1972). In addition, the high content of $\mathrm{MgO}$ and total iron (in part) in samples from Cores 80,82 , and 84 from Hole 467 (Table 1) suggest possible derivation from mafic magma.

The chemical analyses of Hole 467 scoriaceous tuff (recalculated without water) compare favorably with the chemical analysis of a similarly altered basaltic sandstone (hyaloclastite) from the Line Islands (Hole 315A, Leg 33) reported by Kelts and McKenzie (1976). These mafic volcaniclastics, like those in Hole 467 , also were extensively altered to K-feldspar, smectite, and analcime and contain the same type of scoriaceous fragments with spherical to oval vesicles. Labradorite phenocrysts and scarce tachylyte glass shards in the tuffs in Hole 467 also indicate a parent basaltic to basaltic-andesite(?) magma.

Unaltered Vitric Ash, Vitric Tuff, and Pumiceous Tuff

Chemical analyses of unaltered pumice, pumiceous vitric, and vitric ashes from Holes 468, 469, 470, 471, and 473 indicate an andesitic to dacitic composition (using the silica compositional limits for volcanic rocks proposed by Taylor, 1978). The $\mathrm{SiO}_{2}$ content varies from 55 to $63 \%$, the $\mathrm{SiO}_{2} / \mathrm{Al}_{2} \mathrm{O}_{3}$ ratio is about 4 to 5 , and the $\mathrm{TiO}_{2}$ content is usually less than $0.5 \%$. These unaltered ashes are characterized by a low concentration of $\mathrm{MgO}$ and high total alkali content. Even taking into account total alkalis in salts precipitated from interstitial pore water on exposure of the core to air, $\mathrm{Na}_{2} \mathrm{O}$ $+\mathrm{K}_{2} \mathrm{O}$ content reaches $7 \%$ and may be more than $10 \%$. The major oxide composition of these unaltered ashes compares favorably with the major oxides in recent dacitic and andesitic ash fall deposits reported by Heiken (1972). As mentioned in the Petrography section, some whole-rock chemical analyses may be lower in $\mathrm{SiO}_{2}$ content than the $\mathrm{SiO}_{2}$ content determined by the refractive index of the glass shards, because nonpyroclastic impurities (e.g., biotics) were included in the bulk samples.

Comparing the chemical analyses of altered pumiceous and vitric tuffs (Table 1) with unaltered ashes, the water content is higher, the $\mathrm{SiO}_{2}$ content is lower, and the $\mathrm{SiO}_{2} / \mathrm{Al}_{2} \mathrm{O}_{3}$ ratio is slightly lower in the tuffs. No appreciable changes in the $\mathrm{TiO}_{2}$ content were observed. The total iron content is lower than in unaltered ashes presumably because of less authigenic pyrite and iron oxides. The increase of $\mathrm{MgO}$ content in the tuffs versus the ashes probably reflects magnesium fixed in the mineral structure of smectites. The decrease of the $\mathrm{Na}_{2} \mathrm{O}$ and $\mathrm{K}_{2} \mathrm{O}$ in the tuff versus the ashes may be due to greater solubility of these ions in pore waters.

In summary, $\mathrm{Na}, \mathrm{Ca}, \mathrm{K}$, and $\mathrm{Si}$ contents appear to decrease whereas total iron, $\mathrm{Ti}, \mathrm{Mg}$, and $\mathrm{Al}$ contents remain constant or increase in the transformation of ashes to tuffs due to formation of smectite clays and zeolites.

Three vesicular volcanic breccia pebbles in Hole 468B have a chemical composition typical of basaltic andesite except that the $\mathrm{Al}_{2} \mathrm{O}_{3}$ content is slightly high (E. M. Taylor, personal communication, 1981). Clinoptilolite and smectite clays in vesicles in these clasts may account for the high $\mathrm{Al}_{2} \mathrm{O}_{3}$ content.

\section{DIAGENETIC CHANGES}

Smectite clay minerals and zeolites are the main alteration products of volcanic glass in pyroclastic deposits. Because these minerals can be formed under a wide range of geological conditions, many problems of the genesis of these minerals remain. Similar assemblages of alteration minerals can be formed in a variety of depositional and diagenetic environments (Drits and Kossovskaya, 1980; Hay, 1978; Iijima, 1978). Factors influencing zeolite diagenesis include: depth of burial, temperature, time, composition of parent material, composition and $p \mathrm{H}$ of pore water, and whether the system is open or closed to pore water migration (Hay, 1966; Höller and Wirsching, 1978; Surdam and Boles, 1979).

\section{Depth of Burial and Alteration of Glass}

Diagenetic alteration of volcanic glass during burial of marine sediments is one way in which zeolites and smectite clays form. Cenozoic marine vitric ashes exposed on land along the North Pacific margin are characterized by a zone of unaltered andesitic to dacitic volcanic glass that extends from the surface to a depth of 800 meters to $2 \mathrm{~km}$. The depth to which unaltered glass is found in DSDP holes is usually much less. On DSDP Leg 19 in the Gulf of Alaska, unaltered ash occurs to a depth of as much as 400 meters; in Leg 63 holes the maximum depth at which unaltered ash was observed ranges from 128.5 meters (Hole 467) to 274.5 meters (Hole 469, Table 4). The depth of the first altered ash varies from 184.5 meters in Hole 468 to 692.5 meters 
Table 4. Depth of unaltered ashes, altered ashes, and opal-CT zone and present geothermal gradient, Leg 63 .

\begin{tabular}{|c|c|c|c|c|c|c|}
\hline Hole & 467 & 468 & 468B & 469 & 471 & 473 \\
\hline Depth to last unaltered ash (m) & 128.5 & 155.5 & 222.0 & 274.5 & 142.0 & 154.0 \\
\hline $\begin{array}{l}\text { Depth to top of opal-CT } \\
\text { zone }(\mathrm{m})^{\mathrm{a}}\end{array}$ & 538.0 & $184(?)$ & n.d. ${ }^{b}$ & 235.0 & 161.0 & 203.0 \\
\hline Depth to first altered ash (m) & 692.5 & 184.5 & 244.5 & 302.0 & 315.0 & 221.0 \\
\hline $\begin{array}{l}\text { Predicted depth to base of zone } \\
\text { of unaltered volcanic glass }(\mathrm{m})\end{array}$ & 538.0 & 184.0 & n.d. & $302^{\mathrm{c}}$ & 161.0 & 203.0 \\
\hline $\begin{array}{l}\text { Present geothermal gradient } \\
\left({ }^{\circ} \mathrm{C} / \mathrm{km}\right)^{\mathrm{a}}\end{array}$ & $\geq 63$ & n.d. & n.d. & n.d. & $\begin{array}{l}70- \\
151\end{array}$ & $\begin{array}{l}64- \\
160\end{array}$ \\
\hline
\end{tabular}

a Data from Grechin, Pisciotto, and others (this volume).

${ }^{b}$ n.d. = geothermal gradient not measured on site but inferred to be in the range measured in Holes 471 and 473 (Grechin, Pisciotto, and others, this volume),

c Unaltered diatoms, opal-CT, and glass found in volcanic breccia at a depth of 302 meters.

in Hole 467. The thickness of the transitional zone between the last unaltered ash and the first altered ash ranges from 21.5 to 564.0 meters. Somewhere in the stratigraphic interval between the last unaltered ash and the first altered ash in each hole, the first effects of diagenesis of glass occur. However, because ash is not present continuously in this interval, the lower limit of the zone of unaltered ash cannot be drawn on the basis of the observed depths of unaltered versus altered ashes alone.

One method to determine more exactly the depth of alteration of glass is to study the changes of opal-A to opal-CT in the biogenic siliceous sediments that are more common and more uniformly distributed throughout the section. In Cenozoic marine deposits exposed on the west coast of North America, in Japan, and in the Soviet Far East, beds of unaltered volcanic glass are intimately associated with beds of unaltered biogenic siliceous sediments composed of opal-A (Grechin et al., this volume). Deeper in the section, altered ash is associated with siliceous rocks composed of cristobalite (opal-CT), and still lower in the section, with siliceous rocks containing quartz and chalcedony (Bramlette, 1946; Mizutani, 1967; Grechin, 1971, 1976). Data from Leg 63 also show this depth progression of unaltered ash to altered ash in association with transformation of biogenic opal to opal-CT (Table 4). Other diagenetic changes are observed at these same depths including: lithification of sediments, change of composition of pore waters, and in some cases, the appearance of dolomite (Grechin et al., Pisciotto and Mahoney, this volume). This coincidence of the diagenetic transformation of opal-A to opal-CT with the alteration of ash enabled us to predict the depth at which such changes would be evident even in intervals that contain no ash beds through a considerable thickness of section (Table 4).

Although the depth of alteration of volcanic glass predicted on the basis of the transformation of opal-A to opal-CT agrees well with observed occurrences of last unaltered ash and first altered ash for most sites, it does not work in Hole 469. Unaltered glass and pumice occur with a diatomaceous and opal-CT cemented clay matrix in volcanic breccia (Core 33) far below the depth predicted by the opal-A to opal-CT transformation (Table 4). This may be due to a supersaturated condition with respect to silica, which could have occurred in the pore water quite early, preventing further dissolution and hydration of the glass and diatoms. In addition, the detrital clay matrix in this breccia may have resulted in low permeabilities (or a closed system) and prevented widespread migration of this silica-saturated pore water.

At Site 470 and in Hole 472 the entire sedimentary section, 167 meters and 112 meters thick, respectively, belong in the zone of unaltered glass.

\section{Effects of Temperature, Geothermal Gradient, and Geologic Age}

The zone of unaltered glass is thinnest where the measured geothermal gradient is highest (e.g., Sites 471 and 473; Table 4). It appears that greater temperature due to higher geothermal gradients may have a more important effect on the depth of transformation of volcanic glass to smectites and zeolite alteration products than depth of burial.

At all Leg 63 sites, no altered vitric ashes were recognized in deposits younger than late Miocene. Geologic age appears to be not as important a factor in diagenesis (alteration) of vitric ash to tuff as geothermal gradient or depth of burial. For example, in Holes 470, 470A, and 472, shallow-buried middle to upper Miocene strata, which are overlain by 160 meters or less of strata, contain unaltered vitric rhyodacitic-andesitic ash. In other holes $(469,471$, and 473$)$, strata of similar middle to upper Miocene age are covered with a greater thickness of strata and contain altered andesitic to rhyodacitic ashes and tuffs. The only exception to this generalization occurs in Hole 468 where a Pliocene/upper Miocene unconformity represents removal of an unknown thickness of original strata, and middle Miocene tuffs are nearer the surface than the Miocene unaltered vitric ashes at Sites 470 and 472 . Other factors that may act in concert with geothermal gradient in influencing the stratigraphic position (or depth) of the base of the zone of unaltered ash are chemical composition of vitric ash and interstitial waters and whether the system was open or closed.

\section{Composition of Parent Material}

The assemblage of diagenetic minerals in the middle to upper Miocene basaltic scoriaceous tuffs in Hole 467 is different from the diagenetic assemblage in the altered more silicic glassy ashes, vitric tuff, and pumiceous lapilli tuff of the other Leg 63 sites. In Hole 467, the assemblage of diagenetic minerals includes smectite clay minerals, analcime, and $\mathrm{K}$-feldspar. Diagenesis of the andesitic to rhyodacitic altered vitric tuffs and pumiceous lapilli tuffs at the other sites is characterized by formation of clinoptilolite, minor analcime, and dioctahedral Al-smectites. Diagenetic alteration of basaltic glass begins with hydration of the glass from the surface inward, followed by formation of palagonite, smectite clay minerals, and zeolites (Honnorez, 1978).

There are three clay minerals in the scoriaceous tuff and lapilli tuff of Hole 467. Most of these volcaniclastics contain trioctahedral high-magnesium smectite 


\section{I. GRECHIN ET AL.}

clay minerals (saponites), dioctahedral aluminum smectite, and mixed-layer chlorite-smectite. Core 74 , at Site 467 of a scoriaceous altered tuff contains mixed-layer beidellite-montmorillonite. An overall high magnesium content in the basaltic tephra is reflected in the abundance of trioctahedral ferruginous high-magnesium smectite (ferrosaponite) in the altered rock. Similar Mgrich smectite (saponite) has been identified as a product of hydrothermal alteration of basaltic glass in lab experiments by Bischoff and Dickson (1975), Hajash (1975), and Mottl (1976). Under high water/rock ratios, a smectite/chlorite mixed-layer clay is formed (Stakes and Scheidegger, in press). The dioctahedral Al-smectites in Core 74 may be due to heterogeneity in composition of the basaltic scoria or to an admixture of minor altered siliceous glass. Similar trioctahedral smectite and illite/montmorillonite mixed-layer clays in altered Cretaceous basaltic hyaloclastites from the Line Islands Chain have been alternatively interpreted by Kelts and McKenzie (1976) as diagenetic devitrification products under conditions of shallow burial or seafloor weathering (halmyrolysis).

Clinoptilolite is the most common zeolite in the more silicic andesitic to rhyodacitic pumiceous vitric tuffs and tuffaceous sandstones in Holes 468, 468B, and 469 . Genesis of clinoptilolite in marine sediments is favored by high activity of silica and low activity of aluminum. These conditions are most common in sequences of altered ashes that contain rhyolitic to andesitic glass and that are at least 100 meters below the sediment/water interface (Hay, 1978; Hawkins et al., 1978; Iijima, 1978; Kastner, 1979). Analcime is common only in deep-sea sediments that contain mafic tephra (Hay, 1978), such as in Hole 467. Minor analcime occurs in the silicic Miocene andesitic to rhyodacitic pumiceous tuff at Sites 468 through 473. According to Kastner (1979), analcime can result from the reaction:

$$
\text { clinoptilolite }+\mathrm{Na}^{+} \rightarrow \text { analcime }+\mathrm{K}^{+}+\text {quartz }
$$

We, however, observed no petrographic evidence of replacement of clinoptilolite by analcime in the pumiceous lapilli tuffs that would indicate that this reaction had occurred.

Alteration of the Miocene tuffs in Hole 467 is more extensive than at any other site and may reflect the higher susceptibility to alteration of basaltic glass at this site than more silicic Miocene glass at the other sites. We cannot, however, unequivocally decide whether the more extensive alteration is related to more rapid decomposition of basaltic glass or to greater depth of burial (more than $300 \mathrm{~m}$ ) at this site than at the other sites. We favor the composition of the parent material over the depth of burial and geothermal gradient as the controlling factor in this alteration, because at other sites where the present geothermal gradient is higher, silicic glass of the same age shows less alteration than the basaltic glass of Site 467 .

\section{Composition of Pore Waters}

The assemblages of secondary diagenetic minerals in the altered ashes appear to be, in part, related to the chemical composition of the pore waters. Smectites and zeolites may have formed almost simultaneously during interaction of pore waters with volcanic glass, although most zeolites in thin section are pore fillings developed after smectite alteration of the glass. Other initial tuff components, feldspar for instance, underwent much less alteration.

The type of secondary zeolite and smectite minerals formed depends upon a number of physico-chemical parameters of the pore waters: salinity, $p \mathrm{H}$, activity of alkali and alkaline earth ions, $\mathrm{H}_{4} \mathrm{SiO}_{4}, \mathrm{Al}(\mathrm{OH})_{4}$, activity (or partial pressure), and $\mathrm{H}_{2} \mathrm{O}\left(\mathrm{PH}_{2} \mathrm{O}\right.$ ) (Hay, 1978). Only some of these parameters were measured in interstitial waters in the Leg 63 holes. Salinity of interstitial waters changes only slightly with depth and is close to that of seawater; $p \mathrm{H}$ values vary from 7 to 8 (Pisciotto and Mahoney, this volume). Concentrations of $\mathrm{Ca}^{++}$ and $\mathrm{Mg}^{++}$ions change considerably, however. The $\mathrm{Ca}^{++}$content increases with depth, whereas the $\mathrm{Mg}^{++}$ content decreases. This is reflected not only in fixation of $\mathrm{Mg}^{++}$ions in dolomite formed in the sediments, but also in the composition of authigenic magnesium-rich trioctahedral smectite clay minerals in the altered scoriaceous tuff in Hole 467 as well. Folk and Land (1975) also attributed decreases in $\mathrm{Mg}^{++}$ion concentrations to the formation of both dolomite and clays.

Both clinoptilolite and minor analcime occur in the Miocene pumiceous and vitric tuffs of Sites 468, 469, 471 , and 473. Clinoptilolite converts to analcime in marine sediments when the concentration of $\mathrm{Na}^{+}$in interstitial waters ranges from 1.0 to $1.5 \times 10^{4} \mathrm{ppm}$, and burial depths of at least $1.0 \mathrm{~km}$ and temperatures of $84^{\circ} \mathrm{C}$ to $91^{\circ} \mathrm{C}$ are reached (Iijima and Utada, 1971; Iijima, 1974, 1978). This minimum burial depth and these temperatures greatly exceed those measured in the Leg 63 holes. However, in saline alkaline lakes in the western United States this reaction can occur at surface temperature and pressure in devitrification of silicic volcanic glass (Hay, 1966, 1978). There is no evidence, on the basis of present pore water chemistry (Pisciotto and Mahoney, this volume), that the high concentration of $\mathrm{Na}^{+}$needed for the clinoptilolite to analcime transformation was present in the tuffs in Holes 468, 469, 471 , and 473 . The minor amount of analcime in the pumiceous lapilli tuffs commonly occurs in close proximity to plagioclase grains, suggesting that pore water in contact with plagioclase may contain, in a microchemical environment, sufficient $\mathrm{Na}$ to precipitate analcime. Alteration of plagioclase to analcime was also reported by Juteau and others (1979) in altered pillow basalts of Hole 417A, DSDP Leg 51.

\section{Vertical Zonation of Authigenic Minerals}

No vertical zonation in distribution of authigenic zeolites and/or smectites was recognized in the Leg 63 sites, possibly due to insufficient thickness of the section containing altered tuffs. Clinoptilolite and minor analcime occur together in andesitic-dacitic tuffs at Sites 468 and 469. This relationship distinguishes these deepwater altered ashes from altered marine ash deposits exposed on land where the analcime zone commonly 
underlies the clinoptilolite zone (Mizutani, 1967; Iijima, 1978; Hay, 1978).

\section{Hydrothermal Effects (Site 467)}

The assemblage of authigenic minerals of the scoriaceous tuff of Hole 467 includes K-feldspar (high and low sanidine), analcime, smectite, and scarce barite and gypsum. This is a diagenetic mineral assemblage that may reflect a hydrothermal influence. Conditions controlling formation of authigenic $\mathrm{K}$-feldspars in oceanic sediments are not completely understood. Kelts and McKenzie (1976) proposed that diagenetic K-feldspar (adularia) replacing glass and plagioclase in basaltic volcaniclastics of the Line Islands Chain, Leg 33, DSDP resulted from submarine hydrothermal activity. A hydrothermal origin for the authigenic K-feldspar in the scoriaceous tuff of Hole 467 is suggested, because the present thermal gradient $\left(\geq 63^{\circ} \mathrm{C} / \mathrm{km}\right)$ and bottom-hole measured temperatures of $48^{\circ} \mathrm{C}$ to $55^{\circ} \mathrm{C}$ are too low and burial depths are too shallow (on the basis of studies by Iijima and Utada [1971] in Japan) to allow conversion of analcime to $\mathrm{K}$-feldspar.

Higher alkalinity and salinity of pore waters can lower the temperature necessary for these reactions to occur. For example, in deposits of saline alkaline lakes in the western United States these reactions proceed at surface temperature and pressure (Hay, 1966; Sheppard and Gude, 1968). The present composition of pore waters in Hole 467 (Pisciotto and Mahoney, this volume) has no similarity to the composition of pore waters in saline lakes. But Kastner and Seiver (1979) recently showed that feldspar, smectite, and analcime could form from basaltic volcaniclastics at low diagenetic temperature and normal pore water salinities.

Low-temperature hydrothermal activity could change the diagenetic conditions by increasing the temperature and/or the $p \mathrm{H}$ values or by concentrating certain ions in pore waters, thus allowing formation of $\mathrm{K}$-feldspar (sanidine), smectite, and analcime. The presence of gypsum and barite as pore-filling minerals in the scoriaceous tuff is also evidence of some hydrothermal activity. Although gypsum could have been produced by evaporation of pore water during air drying of tuff samples, barite could not form in this way. From sulphur and oxygen isotope analysis, Church (1970) and Cortecci and Longinelli (1972) recognized hydrothermal barite in middle Miocene rocks dredged from the Patton Ridge about $61 \mathrm{~km}$ southeast of Site 467 . Bertine and Keene (1975) also reported similar large barite crystals associated with opal and volcanic debris in the Lau basin. Barite can also be formed in marine sediment as an authigenic precipitate from biological and low-temperature diagenetic processes (Church, 1979). Isotope studies of the barite in Hole 467 would be required to substantiate a hydrothermal versus a diagenetic origin.

Neither the authigenic mineral assemblages nor the reported occurrences of some of these minerals in hydrothermal environments can be considered unequivocal evidence of low-temperature hydrothermal activity. However, when considered together, the evidence leads us to conclude that hydrothermal activity at Site 467 is possible.
This paper does not deal with formation of pyrite in the tuffs, which is present in both altered and unaltered ashes, commonly as a rim lining altered glass vesicles and as isolated cubes in pore spaces. Nor do we consider the geochemical aspects of the diagenetic carbonates in the volcaniclastics and volcanogenic rocks of Sites 467, 468, and 469. Pisciotto and Mahoney (this volume) discuss the downhole genesis and isotope geochemistry of diagenetic carbonates, particularly dolomites, of Leg 63. Calcite occurs mainly as a sparry pore-filling cement in the altered Miocene tuffs in Holes 467 and 469. It formed after the dominant clay and zeolite alteration. Dolomite in the rocks of Hole 468B consists of isolated rhombohedral crystals in the detrital matrix of tuffs and volcanic breccias, which, according to Pisciotto and Mahoney (this volume), are pore fillings rather than replacement of other carbonate minerals. On the basis of carbon and oxygen isotope geochemistry, dolomitization occurred during shallow burial under variable conditions of aerobic and anaerobic oxidation, sulfate reduction, methano-genesis, and low temperature (Pisciotto and Mahoney, this volume).

In summary, the factors most important in diagenesis of the volcaniclastics of Leg 63 are: initial composition of the pyroclastics, local geothermal gradient, composition of pore waters, depth of burial, temperature, sediment permeability, and local low-temperature hydrothermal alteration. There are no depth zonations of zeolites and clay minerals in Leg 63 tuffs comparable to the depth zonations in subaerially exposed Cenozoic marine tuffaceous deposits of the North Pacific margin.

\section{CONCLUSIONS}

Thin beds of unaltered vitric ash and altered tuffs of andesite-rhyodacite composition are scattered throughout Miocene to Quaternary strata encountered in Leg 63 holes. Vitric ashes overlie oceanic crust at the Baja sites (470 through 473 ) and represent ash falls into water from distant explosive intermediate to silicic volcanic sources on mainland Mexico and Baja California. Thick middle to upper Miocene graded tuff and volcanic breccia in the continental borderland holes (467 through 469) off southern California were formed by turbidity currents and some ash falls and are products of local intense volcanic activity. Middle to upper Miocene scoriaceous tuff in Hole 467 was produced by shallow-water phreatomagmatic or magmatic basaltic or possibly andesitic eruptions at a locality isolated from other terrigenous (nonpyroclastic) influences. Epiclastic pumiceous lapilli tuff and volcanic breccia in Holes 468, 468B, and 469 were formed by reworking of freshly erupted dacitic pyroclastics and andesitic to basaltic lavas in a shelf or surf zone environment prior to displacement downslope by density currents and debris flows.

According to Vedder and others (this volume), previous investigators have suggested that the calc-alkaline volcanic rocks of the southern California borderland are remnants of an island arc sequence that was derived from a steepened subduction zone off southern California in the Miocene. Because calc-alkaline rocks from Leg 63 holes (e.g., 468 and 468B) and from deep-sea dredging on the Patton Ridge occur so close to the in- 
ferred Farallon-North American trench, Vedder and others (this volume) hypothesize that these volcanics are more likely related to passage of the ancestral East Pacific Rise by the continental margin rather than to island arc activity.

At most sites, the upper part of the sedimentary section (cored to a depth of about $200 \mathrm{~m}$ ) consists of unaltered volcanic glass shards in the vitric ashes. Below this depth, all tuffaceous interbeds are diagenetically altered, mainly to smectite clays and zeolites. The depth to the top of the zone of altered ashes and tuffs can be predicted by the change of opal-A to opal-CT in the associated biogenic siliceous sediments. No vertical zonation was observed in the distribution of authigenic minerals in Leg 63 holes. The character of the assemblages of authigenic minerals reflects the composition of the initial deposits. Analcime, trioctahedral and dioctahedral smectites, and K-feldspar occur in scoriaceous basaltic tuff in Hole 467. Clinoptilolite, dioctahedral $\mathrm{Al}$-smectite, and minor analcime occur in the andesitic to rhyodacitic altered vitric tuffs at the other sites. Other important factors in this diagenetic alteration are temperature, geothermal gradient, depth of burial, change in composition of the pore water, and whether the pore water system was open or closed during alteration. In addition, low-temperature hydrothermal activity may be an important factor in alteration of scoriaceous basaltic tuff in Hole 467, as indicated by the occurrence of authigenic K-feldspar (sanidine), trioctahedral Mg-rich smectites, barite, analcime, and gypsum(?).

\section{ACKNOWLEDGMENTS}

The authors wish to thank analytical chemists K. A. Stepanova and G. G. Galkovskaya who performed the chemical analyses of the whole-rock and clay mineral separate samples at the chemical analytical laboratory of the Geological Institute of U.S.S.R. Academy of Sciences. We also want to express our appreciation to A. H. Soeldner (of the Electron Microscopy Facility, Oregon State University) who operated the scanning electron microscope and took photographs of pyroclastic samples. We appreciate the assistance of Reed Glasmann, Soils Department, Oregon State University, who reviewed the clay mineral section. Oregon State University General Research Fund and the National Science Foundation under the auspices of the Deep Sea Drilling Project provided some financial support for some research phases of this investigation. Hugh McLean of the U.S. Geological Survey kindly loaned thin sections of the Blanca Formation on Santa Rosa and Santa Cruz islands for petrographic comparison with the tuffs in Holes 467, 468, and 468B. Finally, we gratefully acknowledge the help of Wendy A. Niem in editing, drafting, and typing this paper under a time constraint.

\section{REFERENCES}

Barth, T. F. W., 1969. Feldspars: New York (John Wiley and Sons, Inc.).

Bertine, K. K., and Keene, J. B., 1975. Submarine barite-opal rocks of hydrothermal origin. Mar. Chem., 5:291-296.

Bischoff, J. L., and Dickson, F. W., 1975. Seawater-basalt interaction at $200^{\circ} \mathrm{C}$ and 500 bars: implications for origin of seafloor heavymetal deposits and regulation of seawater chemistry. Earth Planet. Sci. Lett., 25:385-397.

Bonatti, E., 1970. Deep sea volcanism. Naturwissenschaften, 57:379384.

Bond, G. C., 1973. A Late Paleozoic volcanic arc in the eastern Alaska Range, Alaska. J. Geol., 81:557-575.

Bramlette, M. N., 1946. The Monterey Formation of California and the origin of its siliceous rocks. U.S. Geol. Surv. Prof. Pap. 212.
Chamberlain, C. K., 1978. Recognition of trace fossils in cores. In Basan, P. B. (Ed.), Trace Fossil Concepts: Soc. Econ. Paleontol. Mineral. Short Course No. 5, pp. 119-166.

Church, T. M., 1970. Marine barite [Ph.D. dissert.]. University of California, San Diego.

1979. Marine barite. In Burns, R. G. (Ed.), Marine Minerals: Mineralogical Soc. Am. Short Course Notes, 6:175-209.

Cortecci, G., and Longinelli, A., 1972. Oxygen isotope variations in a barite slab from the sea bottom of California. Chem. Geol., 9: 113-117.

Drits, V. A., and Kossovskaya, A. G., 1980. Geocrystallochemistry of rock-forming dioctahedral smectites. Lithol. Miner. Resour. (Engl. Transl.), 15:84-114.

Drits, V. A., and Sakharov, B. A., 1976. X-ray structural analysis of mixed-layer minerals. Trans. Geol. Inst. U.S.S.R. Acad. Sci., 295: $1-256$.

Fernandez, H. E., 1969. Notes on the submarine ash flow tuff in Siargao Island, Suriagao del Norte. Philipp. Geol., 23:29-36.

Fisher, R. V., and Charlton, D. W., 1976. Mid-Miocene Blanca Formation, Santa Cruz Island, California. In Howell, D. G. (Ed.), Aspects of the Geologic History of the California Continental Borderland: Am. Assoc. Pet. Geol. Pac. Sec. Misc. Publ. 24, pp. 228-240.

Fisher, R. V., and Waters, A. C., 1970. Base surge bed forms in maar volcanoes. Am. J. Sci., 268:157-180.

Fiske, R. S., 1963. Subaqueous pyroclastic flows in the Ohanapecosh Formation, Washington. Geol. Soc. Am. Bull., 74:391-406. 1969. Recognition and significance of pumice in marine pyroclastic rocks. Geol. Soc. Am. Bull., 80:1-8.

Fiske, R. S., and Matsuda, T., 1964. Submarine equivalents of ash flows in the Tokiwa Formation, Japan. Am. J. Sci., 262:76-106.

Folk, R. L., and Land, L. S., $1975 . \mathrm{Mg} / \mathrm{Ca}$ ratio and salinity: two controls over crystallization of dolomite. Am. Assoc. Pet. Geol. Bull., 59:60-68.

Friedman, G. M., 1959. Identification of carbonate minerals by staining methods. J. Sediment. Petrol., 29:87-97.

Gastil, G., Krummenacher, D., and Minch, J., 1979. The record of Cenozoic volcanism around the Gulf of California. Geol. Soc. Am. Bull., 90:839-857.

Goldsmith, J. R., and Laves, F., 1954. Potassium feldspars structurally intermediate between microcline and sanidine. Geochim. Cosmochim. Acta, 6:100-118.

Grechin, V. I., 1971. Miocene siliceous rocks of western Kamchatka. Lithol. Miner. Resour. (Engl. Transl.), 4:117-123.

1976. Miocene deposits of west Kamchatka (sedimentation and catagenesis). Trans. Geol. Inst. U.S.S.R. Acad. Sci., 282: 1-138.

Greene-Kelly, R., 1953. Identification of montmorillonite. J. Soil Sci., $4: 233-237$.

Hajash, A., 1975. Hydrothermal processes along mid-ocean ridges: an experimental investigation. Contrib. Mineral. Petrol, , 53:205-226.

Hawkins, D. B., Sheppard, R. A., and Gude, A. J., III, 1978. Hydrothermal synthesis of clinoptilolite and comments on the assemblage phillipsite-clinoptilolite-mordenite. In Sand, L. B., and Mumpton, F. A. (Eds.), Natural Zeolites-Occurrence, Properties, Use: New York (Pergamon Press), pp. 337-344.

Hay, R. L., 1978. Geologic occurrence of zeolites. In Sand, L. B., and Mumpton, F. A. (Eds.), Natural Zeolites-Occurrence, Properties, Use: New York (Pergamon Press), pp. 135-143.

1966. Zeolites and zeolitic reactions in sedimentary rocks. Geol. Soc. Am. Spec. Paper 85.

Heiken, Grant, 1972. Morphology and petrography of volcanic ashes. Geol. Soc. Am. Bull., 83:1961-1988.

Höller, H., and Wirsching, U., 1978. Experiments on the formation of zeolites by hydrothermal alteration of volcanic glass. In Sand, L. B., and Mumpton, F. A. (Eds.), Natural Zeolites-Occurrence, Properties, Use: New York (Pergamon Press), pp. 329-336.

Honnorez, J., 1978. Generation of phillipsites by palagonitization of basaltic glass in sea water and the origin of K-rich deep-sea sediments. In Sand, L. B., and Mumpton, F. A. (Eds.), Natural Zeolites-Occurrence, Properties, Use: New York (Pergamon Press), pp. 245- 258.

Honnorez, J., and Kirst, P., 1975. Submarine basaltic volcanism: morphometric parameters for discriminating between hyaloclastites and hyalotuffs. Bull. Volcanol., 39:441-465. 
Hoss, H., and Roy, R., 1960. Zeolite studies, III: On natural phillipsite, gismondite, harmotome, chabazite, and gmelinite. Beitr. Mineral. Petrol., 7:389-408.

Howell, D. G., and McLean, Hugh, 1976. Middle Miocene paleogeography, Santa Cruz and Santa Rosa islands. In Howell, D. G. (Ed.), Aspects of the Geologic History of the California Continental Borderland: Am. Assoc. Pet. Geol. Pac. Sec. Misc. Publ. 24, pp. 266-293.

Iijima, A., 1974. Clay and zeolitic alteration zones surrounding Kuroko Deposits in the Hokuroku Distrist, northern Akita, as submarine hydrothermal-diagenetic alteration products. In Ishihara, S., Kanehira, K., Sasaki, A., et al., (Eds.), Geology of Kuroko Deposits: Mining Geol. Spec. Iss., 6:267-289.

1978. Geological occurrence of zeolite in marine environments. In Sand, L. B., and Mumpton, F. A. (Eds.), Natural Zeolites-Occurrence, Properties, Use: New York (Pergamon Press), pp. $175-198$.

Iijima, A., and Utada, M., 1971. Present-day zeolitic diagenesis of the Neogene geosynclinal deposits in the Niigata oil field, Japan. Molecular Sieve Zeolites-I, Advances in Chemistry Series 101. Am. Chem. Soc., pp. 342-349.

Juteau, T., Noack, Y., Whitechurch, H., et al., 1979. Mineralogy and geochemistry of alteration products in Holes 417A and 417D basement samples (Deep Sea Drilling Project Leg 51). In Donnelly, T., Francheteau, J., Bryan, W., Robinson, P., Flower, M., Salisbury, M., et al., Init. Repts. DSDP, 51, 52, 53, Pt. 2: Washington (U.S. Govt. Printing Office), 1273-1298.

Kastner, M., 1979. Zeolites. In Burns, R. G. (Ed.), Marine Minerals: Mineralogical Soc. Am. Short Course Notes, 6:111-122.

Kastner, M., and Seiver, R., 1979. Low temperature feldspars in sedimentary rocks. Am. J. Sci., 279:435-479.

Kelts, K., and McKenzie, J. A., 1976. Cretaceous volcanogenic sediments from the Line Island Chain: diagenesis and formation of K-feldspar, DSDP Leg 33, Hole 315A and Site 316. In Schlanger, S. O., Jackson, E. D., et al., Init. Repts. DSDP, 33: Washington (U.S. Govt. Printing Office), 789-831.

Lajoie, J., 1979. Volcaniclastic rocks. In Walker, R. G. (Ed.), Facies Models: Geoscience Canada, Reprint Series I, pp. 191-200.

Lancelot, Y., Hathway, J. C., and Hollister, C. D., 1972. Lithology of the sediments from the western North Atlantic, Leg 11, Deep Sea Drilling Project. In Hollister, C. D., Ewing, J. I., et al., Init. Repts. DSDP, 11: Washington (U.S. Govt. Printing Office), 901-973.

McBirney, A. R., 1963. Factors governing the nature of submarine volcanism. Bull. Volcanol., 26:455-469.

McLean, H., Crowe, B. M., and Howell, D. G., 1976. Source of Blanca Formation volcaniclastic rocks and strike-slip faulting on Santa Cruz Island, California. In Howell, D. G. (Ed.), Aspects of the Geologic History of the California Continental Borderland: Am. Assoc. Pet. Geol. Pac. Sec. Misc. Publ. 24, pp. 294-308.

McLean, H., Howell, D. G., and Vedder, J. G., 1976. Miocene strata on Santa Cruz and Santa Rosa Islands-a reflection of tectonic events in the Southern California Borderland. In Howell, D. G. (Ed.), Aspects of the Geologic History of the California Continental Borderland: Am. Assoc. Pet. Geol. Pac. Sec. Misc. Publ. 24, pp. 242-255.

Middleton, G. V., and Hampton, M. A., 1973. Sediment gravity flows: mechanics of flow and deposition. In Middleton, G. V., and Bouma, A. H. (Eds.), Turbidites and Deep-Water Sedimentation: Soc. Econ. Paleontol. Mineral. Pac. Sec. Short Course Lecture Notes, pp. 1-38.

Mizutani, S., 1967. Kinetic aspects of diagenesis of silica in sediments. J. Earth Sci., 15:419-436.

Mottl, M. J., 1976. Chemical exchange between seawater and basalt during hydrothermal alteration of the oceanic crust [Ph.D. dissert.]. Harvard University, Cambridge.
Murai, I., 1961. A study of the textural characteristics of pyroclastic flow deposits in Japan. Bull. Earthquake Res. Inst., 39:133-248.

Mutti, E., 1965. Submarine flood tuffs (ignimbrites) associated with turbidites in Oligocene deposits of Rhodes Island (Greece). Sedimentology, 5:265-288.

Niem, A. R., 1977. Mississippian pyroclastic flow and ash-fall deposits in the deep-marine Ouachita flysch basin, Oklahoma and Arkansas. Geol. Soc. Am. Bull., 88(1):49-61.

Pirsson, L. V., 1915. The microscopical characters of volcanic tuffsa study for students. Am. J. Sci. (4th ser.), 40:191-211.

Pratt, R. M., Scheidegger, K. F., and Kulm, L. D., 1973. Volcanic ash from DSDP Site 178, Gulf of Alaska. In Kulm, L. D., von Huene, R., et al., Init. Repts. DSDP, 18: Washington (U.S. Govt. Printing Office), 833-834.

Schmid, R., 1981. Descriptive nomenclature and classification of pyroclastic deposits and fragments. Recommendations of the IUGS Subcommission on the Systematics of Igneous Rocks. Geology, 9:41-43.

Sheppard, R. A., and Gude, A. J., 1968. Distribution and genesis of authigenic silicate minerals in tuffs of Pleistocene Lake Tecopa, Inyo County, California. U.S. Geol. Survey Prof. Paper 597.

Sheridan, M. F., 1971. Particle-size characteristics of pyroclastic tuffs. J. Geophys. Res., 76:5627-5634.

Stakes, D. S., and Scheidegger, K. F., in press. Temporary variations in secondary minerals from Nazca Plate basalts. In Kulm, L. D., Dymon, J., Dasch, E. J., et al. (Eds.), Nazca Plate: Crustal Formation and Andean Convergence: Geol. Soc. Am. Mem.

Surdam, R. C., and Boles, J. R., 1979. Diagenesis of volcanic sandstones. In Scholle, P. A., and Schluger, P. R. (Eds.), Aspects of Diagenesis: Soc. Econ. Paleontol. Mineral. Spec. Publ. 26, pp. 227-242.

Tasse, N., Lajoie, J., and Dimroth, E., 1978. The anatomy and interpretation of an Archean volcaniclastic sequence, Noranda region, Quebec. Can. J. Earth Sci., 15:874-888.

Taylor, E. M., 1978. Field geology of S.W. Broken Top quadrangle, Oregon. Oregon Dept. Geol. Miner. Ind. Spec. Pap. 2.

Utada, M., 1971. Zeolitic zoning in the Neogene pyroclastic rocks of Japan. Sci. Pap. Coll. Gen. Educ. Univ. Tokyo, 21:189-221.

van der Lingen, G. J., 1973. The Lord Howe Rise rhyolites. In Burns, R. E., Andrews, J. E., et al., Init. Repts. DSDP, 21: Washington (U.S. Govt. Printing Office), 523-539.

Walker, R. G., 1975. Generalized facies models for resedimented conglomerates of turbidite association. Geol. Soc. Am. Bull., 86: 737-748.

Walker, R. G., and Mutti, E., 1973. Turbidite facies and facies associations. In Middleton, G. V., and Bouma, A. H. (Eds.), Turbidites and Deep-Water Sedimentation: Soc. Econ. Paleontol. Mineral. Pac. Sec. Short-Course Lecture Notes, pp. 119-157.

Williams, H., Turner, F. J., and Gilbert, C. M., 1954. Petrography: San Francisco (W. H. Freeman and Company), pp. 26-30.

Wright, T. L., 1968. X-ray and optical study of alkali feldspar: II. an $\mathrm{X}$-ray method for determining the composition and structural state from measurement of $2 \theta$ values from three reflections. Am. Mineral., 53:88-104.

Yamada, E., 1973. Subaqueous pumice flow deposits in the Onikobe Caldera, Miyagi Prefecture, Japan. J. Geol. Soc. Jpn., 79: 585-597.

Zolotarev, B. P., Choporov, D. Y., and Voitov, G. I., 1979. Petrochemistry of basalts and distribution of organic gases: Holes 407 , 408, 409, 410A, 411, 412, and 413, DSDP Leg 49. In Luyendyk, B. P., Cann, J. R., et al., Init. Repts. DSDP, 49: Washington (U.S. Govt. Printing Office), 727-744. 